NBER WORKING PAPER SERIES

\title{
FROM THEORY TO PRACTICE: \\ FIELD EXPERIMENTAL EVIDENCE ON EARLY EXPOSURE \\ OF ENGINEERING MAJORS TO PROFESSIONAL WORK
}

\author{
Kevin J. Boudreau \\ Matt Marx \\ Working Paper 26013 \\ http://www.nber.org/papers/w26013 \\ NATIONAL BUREAU OF ECONOMIC RESEARCH \\ 1050 Massachusetts Avenue \\ Cambridge, MA 02138 \\ June 2019
}

We appreciate helpful comments from seminar participants at the NBER productivity seminar, ESMT, the University of Maryland, and Boston University. This work was conducted with financial support and advice from the Research Institute for Experiential Learning Science (RIELS); and we are especially grateful for advice and support from Susan Ambrose and Cidgem Talgar and colleagues Tony Armelin, John Bielaus, Esther Chewning, Roy Dalsheim, Joy Erb, Janna Ferguson, Rana Glasgal, Mary Kane, Shane Karcz, Laura Kenney, Candace Martel, Lorraine Mountain, Charles Price, Chris White, and Ellen Zierk. We also thank Muyang Zhou and Bochau Sun for research assistance. We would also like to acknowledge financial support from Boston University and Northeastern DMSB. The views expressed are those of the authors alone and do not necessarily reflect those of the institutions, funders or supporters and advisors involved with this study. Errors are our own. The views expressed herein are those of the authors and do not necessarily reflect the views of the National Bureau of Economic Research.

NBER working papers are circulated for discussion and comment purposes. They have not been peer-reviewed or been subject to the review by the NBER Board of Directors that accompanies official NBER publications.

(C) 2019 by Kevin J. Boudreau and Matt Marx. All rights reserved. Short sections of text, not to exceed two paragraphs, may be quoted without explicit permission provided that full credit, including $\odot$ notice, is given to the source. 
From Theory to Practice: Field Experimental Evidence on Early Exposure of Engineering Majors to Professional Work

Kevin J. Boudreau and Matt Marx

NBER Working Paper No. 26013

June 2019

JEL No. I21,J2,O3

\begin{abstract}
Young workers typically enter the professional labor market only after completing higher education. We investigate how earlier professional work experience affects skilled worker development. In a field experiment, 1,787 Engineering majors were randomly assigned to 6month work terms to begin either in the second or third year of studies. Early exposure caused systematic differences in inclination to take Engineering elective courses, choice of major, and the probability of persisting in Engineering years later-consistent with engagement, retention, and sorting effects. Early exposure notably increased academic and professional outcomes of lower-income students.
\end{abstract}

Kevin J. Boudreau

D'Amore-McKim School of Business

Northeastern University

360 Huntington Avenue

Boston, MA 02115

and NBER

k.boudreau@northeastern.edu

Matt Marx

Boston University

595 Commonwealth Avenue, 643A

Boston, MA 02215

mattmarx@bu.edu 


\section{Introduction}

Young people typically spend two decades or more in formal academic studies before taking a first professional job upon graduating with a university degree. This pattern is consistent with basic tenets of human capital theory (Becker, 1964), which emphasizes accumulating human capital before engaging in practice and becoming fully productive as a worker. This idea might be doubly relevant for more technical and scientific fields, as increasingly specialized knowledge is required to contribute to increasing knowledge demands in the technical production process (Jones, 2009). Thus, roughly speaking, the prevailing model of higher education is one of "theory-then-practice." In this paper, we investigate how programmatic deviations from the prevailing theory-then-practice approach to higher education - providing young people with earlier exposure to the professional labor market in their fields prior to graduating - affects a range of academic and professional outcomes. We present evidence from a rare, large-scale field experiment in which Engineering majors were programmatically exposed to substantial junior Engineering roles before graduating from their Engineering program. The results shed light on tradeoffs implicit in the design of our higher education institutions while speaking to effects on developing skilled workers in Engineering, Applied Sciences.

The prevailing theory-then-practice model is not without its detractors - and has particularly received questioning in Applied Sciences and Engineering (Schumann et al., 2002; Dym et al., 2005). From their inception as university programs in the late 1800s through the following century, Engineering programs in the United States evolved from a relatively applied education to progressively more conceptual and mathematical training in response to an increasing array of technologies demanding underlying technological and scientific knowledge (Seely, 1999). By the 1980s, undergraduate Engineering programs had become as theoretical and mathematical as any undergraduate degree, including programs in Physical Sciences and Mathematics. The perception among some employers, university administrators, and education policymakers at the time was that the increasingly abstract, conceptual and mathematical content of programs left junior Engineers ill-prepared to enter the full-time workforce (Seely, 1999; Jørgensen, 2007). As a consequence, since the 1990s, there has been a countervailing trend across many American Universities towards incorporating varying degrees of practical training and experience into the curriculum. For example, since that time, the majority of Engineering programs in the United States now include some form of senior year project or, at least, practical lab courses involving the creation of working prototypes. Moreover, several dozen Engineering schools more fundamentally depart from the theory-then-practice model by programmatically incorporating professional work terms within their undergraduate programs.

The controversy and variety of approaches raise questions regarding whether prevailing higher education approaches and their alternatives could come with certain kinds of tradeoffs, particularly as regards the transition from theory to practice. In principle, exposure to professional work 
experience before graduating could have many effects. The net of these effects should, therefore, be an empirical question. Consider, for example, adding professional work requirements to a degree can prolong the degree, add additional stresses, and reduce the time that would otherwise be spent in leisure. Work requirements could also disrupt or distract from regular academic studies. A worker who has yet to complete their degree will also not yet benefit from a full complement of advanced coursework.

On the other hand, theoretical and practical knowledge accumulation and development could perhaps somehow be complementary to one another. Gaining early exposure could also provide young people with early familiarity with work context and professional norms, culture, and conduct. There might also be an opportunity to expose young people to a professional network and mentors, while also beginning to earn an income before graduating from one's degree. To our knowledge, there are not yet systematic studies evaluating causal evidence of fundamental deviations in timing or sequence from the prevailing theory-then-practice model. (The following section, however, reviews closely-related literatures.)

These possible tradeoffs and tensions associated with the transition from theory to practice could be especially relevant to Engineering and Applied Sciences. The close relationship between theory and practice in skills development is especially inherent to the applied science nature of Engineering. It is also the case that many high school students choose to enter into Engineering to "build things" (Brophy, et al. 2008) and then encounter a highly theoretical and mathematical undergraduate program (Felder and Silverman, 1998; Felder, 1982; Felder et al. 2000). Early exposure could provide "connective tissue" between largely theoretical academic training and expected careers (Seely, 1999) and enable students to receive early feedback on potential careers, which they choose under considerable uncertainty (Froyed et al., 2012; Manski, 1993; Bleemer and Zafar, 2018). The supply of Engineering talent is also a pressing policy issue, given the national interest in ensuring a robust pipeline of technical workers and a history of finding this pipeline is "leaky," with a majority of graduates leaving the field (Atkinson, 2000; National Academy of Engineering, 2005; National Research Council, 2011; White House Press Release 2015, 2017). More generally, the supply of technical workers has been linked to patenting, entrepreneurship, and employment growth (e.g., Murphy, et al. 1991; Kerr, 2013; Maloney and Caicedo, 2016).

We collaborated with a top-40 Engineering school in the United States to examine causal effects of varying the timing of exposure to participation on the professional labor market and professional work experiences. At this Engineering school, all students complete at least one 6month professional work term in Engineering (most complete three). Students were randomly assigned to either begin their first work term in the 2nd year or 3rd year and then rotated between on-campus academic terms (i.e., classwork) and off-campus work terms until a semester before graduating, allowing us to estimate effects of this incremental shift in timing of first exposure on post-treatment, longer-term academic and professional outcomes. The randomization and data analysis here relates to 1,787 of the Engineering majors admitted in the regular fall intake from 
2009 to 2013 across Mechanical, Civil, Chemical, Electrical, Industrial, Computer, and Biological Engineering. In association with this randomization, we collected and matched several data sets related to the entire academic and professional histories of these individuals from their initial entry to the program and their professional careers during and following the program. Our research design provides a unique opportunity to attempt to measure post-treatment outcomes across a wide range of academic and professional outcomes.

We find a set of patterns that are consistent with earlier exposure leading to greater engagement and retention in Engineering, while also shaping sorting of different types of work into different areas of the field. For example, incrementally earlier professional work exposure causes students to take a higher proportion of their electives in Engineering. Highest-GPA students are more likely to continue in Engineering after graduation, and especially so in graduate school. Early exposure to work experience also leads to higher switching of majors in the post-treatment period, with a systematic tendency to switch to Engineering subfields earning higher wages.

Early exposure to work experience has especially strong effects on lower-income students (i.e., those receiving financial aid above 50th percentile). Early exposure leads lower-income students to attain higher grades, to attain higher wages, and to join larger employers upon graduation. These patterns are consistent with some combination of alleviating financial stresses or providing perspective from a group that might have fewer relatives or social network represented in the profession.

The most apparent evidence of negative effects of entering into professional work before graduation can be seen in negative effects of early work experience on the grades of international students who, on average, perform below the population and then perform worse when exposed to earlier work experience. There is also statistically weak evidence that early experience also negatively affects low-GPA students. These patterns are consistent with early professional market entry creating additional burdens and challenges for individuals, and with perhaps some international students and low-GPA students facing a higher degree of these burdens and challenges.

Equally notable are areas where the intervention had little effect. For example, we fail to find evidence that older students are affected substantially differently, suggesting that added time and life experience per se are not a major factor in determining academic and professional outcomes here. We also fail to find systematic evidence of early work experience disinclining students from academic studies. Apart from the case of international students and low-GPA students, those with early exposure achieved higher grades than the rest. It is also the case that particularly the highest-GPA students receiving the early exposure become more inclined to pursue graduate school. Another area where a lack of results is especially important is in regards to females. Although females tend to achieve higher grades and graduation rates on average than males (and those receiving the early treatment perform even slightly more highly), the intervention does little to diminish the 10 percent difference between females and males in their willingness to pursue Engineering employment upon graduating. 
The findings have potentially important implications for understanding the functioning of higher education institutions, in a context of rising fees and public debate about the extent to which universities produce workers ready to enter the labor force (Casner and Barrington, 2006; Association of American Colleges and Universities, 2013, 2015). The evidence here suggests that, at least to the extent that added burdens and challenges could be borne by the student in question, early exposure to work in one's field can result in more engagement, greater (and possibly more informed) sorting and self-selection. Greater development and success in outcomes is also achieved, at least among lower-income students.

It is possible these findings and implications are especially relevant to Applied Sciences and Engineering, where engagement and sorting could plausibly be associated with alleviating high uncertainty among young Engineering majors in their understanding the field and the nature of these professions, norms, work demands, and market conditions and opportunities (Karataş et al. 2016). Early entry to professional work experience relates closely too to a tension between theory and practice that has been noted in the profession for a century and more (Seely, 1999).

\section{Related Literature}

In studying the transition from theory to practice in one's field, this paper can be understood to relate to research estimating effects of largely part-time or summer work experience that individuals might engage in during high school or college education (as distinct from a programmatic entry to the professional labor market in one's field). For example, using broadly-sampled national U.S. surveys. Light (2001) finds limited gains from pre-graduation work experience and caution against drawing strong inferences from observational data such as the National Longitudinal Survey of Youth (NLSY), which is frequently used to study the returns to early work experience (see also Light and Ureta, 1995). Ashworth et al. (2017) also analyze the same large-scale national survey data used by Light using a dynamic structural model that contemplates selection into work experience and to education. They estimate positive returns to work experience and especially to full-time work experience before graduation, whose returns are similar to those of schooling. Likewise, on estimation of effects of working studying, Stinebrickner and Stinebrickner (2003) caution that in view of work decisions being endogenous, it is difficult to interpret observed relationships between this sort of work experience and performance outcomes. Apart from differences in research design, the current paper instead studies a defined population of Engineering students' who are systematically exposed to professional work experience in their field. The work terms here are full-time professional jobs; not part-time or contemporaneous with study terms.

A separate research tradition within Education Policy, much of this focused on Engineering, studies work term and internship programs specifically, with a rich tradition of descriptive microstudies (e.g., Lindenmeyer, 1967; Felder, et al., 1988; Crawley et al., 2007; Talgar et al., 2017). Within this tradition are several studies that attempt to more directly examine performance out- 
comes with correlational evidence between participation in experiential education programs and student outcomes (e.g., Blair et al. 2004; Van Gyn, 1997). This tradition does not yet attempt to estimate causal effects.

More generally, this paper speaks to longstanding questions of training and human capital investment (Schultz, 1961; Becker, 1994; Blundell, et al. 1999; Heckman and Rubinstein, 2001). The current work has parallels to studies related to the accumulation of human capital during higher education (e.g., Card, 1995; Oreopoulos and Petronijevic, 2013; Bowen, 2018), albeit in relation to professional work experience. In the current study, we also exploit experimental random assignment, whereas studies of returns to higher education more often exploit natural experiments (but see Angrist and Chen (2011) for an exception). There are also a small number of papers within the returns to education tradition that attempt to estimate effects of possible interruptions to education where students either leave school work temporarily or engage in work simultaneous to schooling, finding limited effects (Griliches, 1981). For example, using National Labor Survey data, Light, (1995) finds evidence of a very slight negative association in the case of females, but no such evidence in the case of males.

The effects we are able to observe here are also consistent with young people obtaining useful signals regarding potential matches in the labor market and experience to reduce considerable uncertainty about their chosen profession (e.g., Manski, 1993; Bettinger et al., 2009; Bleemer and Zafar, 2018).

\section{Research Design}

Context. The context for this study is a top-40 undergraduate Engineering program in the United States. The program enrolls roughly 400 students per year. Majors include Biological, Chemical, Civil, Environmental, Electrical, Computer, Mechanical, and Industrial Engineering. Standardized SAT test scores upon admittance average 719 and high school grade point average (GPA) averages 3.99 over the observation period. Similar to national averages, eighty-four percent of students received financial aid (average award $=\$ 17,267$ ). Similar to national averages, 22.3 percent of enrolled students in the program are female. Within the program, these students achieve an average GPA of 3.38. The rate of graduation is high relative to national averages, with 93.9 percent successfully completing their degree.

Students in the program participate in at least one 6-month professional work term and at most three (average $=2.73$ ), with only a few exceptional cases. Prior to each work term, students apply and compete with one another for positions in an internal labor market that is curated and maintained by program coordinators. Curation of the market involves enlisting and maintaining relationships with industry partners and individual hiring managers to identify suitable positions for junior engineers. Program coordinators also provide training and counsel to students. The market clears through a process of students applying to advertised positions, followed by interviews, 
and then to sequential time-limited offers made by employers to applicants. In the small minority of cases in which students are not matched to positions through usual market clearing, program officers engage in ad hoc networking with prospective employers to find a suitable match.

The bulk of firms who hire students for work terms do so on an ongoing basis. The six-month work term allows student Engineering positions to be regularly handed-off from one student to another during the year. Most positions are in the U.S., and at approximately 94 percent are Engineering positions (with some students taking positions in business, finance, or government). Popular employers include General Electric, Boston Scientific, Johnson and Johnson, Nxstage Medical, and Bose. The average wage paid in the sample is $\$ 19$ per hour.

Randomized Timing of First Exposure to the Engineering Labor Market. Engineering students at this university typically take five years to complete the program. During the first three semesters - i.e., fall and spring semesters of the first year and the fall of the second year-all students are on campus and take the same classes. The students we study of are from entering cohorts from 2009 to 2013 in the regular fall intake.

Students within each cohort are randomly assigned by the program to begin their 6-month work term in the second (spring) semester of their second year or the first (fall) semester of their third year. Therefore, the treatment period begins relatively early in the academic program, roughly one-third of the way through the program (i.e., the later half of second year, divided by five years.) This early "pre-treatment" period of the program is also the most standardized, with standard classes and even considerable overlap in foundational courses in mathemematics and Engineering principles. Randomization was implemented by university administrators by sorting students alphabetically and alternately assigning names from top to bottom of the list to the Early and Late groups.

As will be reviewed in presenting descriptive patterns from the data set below, this results in equivalent sets of students being first exposed to work experience in Engineering at incrementally different times. They also graduate at the same moment with the same coursework and same number of work terms. Therefore, the treatment involves only time-shifting the earliest exposure. Further, while particular job assignments and wages are endogenous outcomes in the university labor market (just as is the case in joining full-time jobs upon graduation), the distribution of wages in the early assignment in second year and the later assignment in the third year is precisely the same.

It should be mentioned too that this randomization served the university's objective of "smoothing" the number and types of students from term to term. The university actively seeks to maintain a stable supply of and demand for junior Engineering workers throughout the year, while at the same time maintaining equivalent supply of and demand for academic courses and other on-campus services. This minimizes variation in staffing and operational requirements. The system also leads students to appear to be indifferent as to which timing they are assigned to (at least on the basis 
of large number of informal anecdotal accounts from Engineering majors and administrators we interviewed.) The system is also therefore well-geared to employers being able to reliably staff a given position year-round with a comparable worker.

\section{Experimental Population \& Data Set}

The study population covers all regularly-admitted students subject to the randomization between 2009 and 2013. A number of specialized programs and special cases of students admitted outside the regular fall intake were exempt from the randomization and not included in the analysis. We also exclude a small number of individuals who fail to achieve a very minimum grade point average of 2.0 in the pre-treatment period. Thus, the experimental population under study includes 1,787 individuals over 3 cohorts.

Given the wide range of possible effects of early exposure to professional work experience in one's field (as discussed in the Introduction) our interest is to observe a wide range of academic and professional measures. In close collaboration with the university, we assembled and matched data covering a range of choices and outcomes related to academic and professional outcomes. We matched admissions data (on applications prior to joining the university) to registrar data (covering academic coursework) and work term data. Prior to anonymizing, these data were also matched with Linkedin data, hand-collected by research assistants. Student names were retrieved from LinkedIn manually, comparing dates of attendance at the top-40 U.S.-based Engineering program with registrar records. The only profiles with jobs and/or graduate schools following the undergraduate program were used. We found informative LinkedIn profiles for 79 percent of graduates (with statistically identical coverage across Early and Late groups). Apart from variables related to academic and professional careers, the data set includes demographic variables such as gender, race, whether they are international students, and financial assistance grants. A description of the main variables used in the analysis are summarized in Table 1.

\section{$<$ TABLE $1>$}

Although Early and Late group assignments were randomized according to the procedures described above, it is useful to examine whether the resulting groups are balanced along observables. Table 2 shows that Early and Late groups are similar in age, gender, financial aid, credits completed and multiple measures of student quality - high school GPA, high school standardized tests, and (pre-treatment) GPA as of the 3rd semester, credits completed. There are slight differences in the percentage of non-U.S. students across groups; explicitly including this variable as a control in any of the reported models has no impact on reported results.

$<$ TABLE 2> 
Table 2 also examines balance among characteristics regarding the work-term jobs to which the Early and Late groups are assigned. The observable characteristics of these work terms in which the groups participate - wages, domestic versus international jobs, percentage of purely Engineering jobs - are statistically indistinguishable. (Almost all work-term assignments are in an Engineering job, as determined by the firm's industry or, if the firm operates in multiple industries, the student's job title at the company.) These descriptive comparisons indicate that the incremental difference in timing of Early and Late groups is not associated with differences in the nature or quality of jobs, as the groups begin their first work terms.

The research design balances characteristics of the environment and opportunities for Engineering students. This is first accomplished by exploiting variation within a single Engineering program at a single institution, given the randomization procedure. Further, university administrators design the system with explicit goal of "smoothing" all features of program operation throughout the year. This not only applies to the availability of employers and position, but courses on offer, staffing and overall university operations.

Given that students in the Early and Late groups are not on campus at the same time following the third semester (except for the final semester before graduation), Table 2 also compares the courses offered to the different groups. Students in the Late group have slightly more courses available than those in the Early group, including somewhat more Engineering courses. (We will find that, in fact, the Early group takes a greater number of Engineering courses.)

\section{Results}

\subsection{Early Exposure \& Academic Performance}

\section{Post-Treatment Grade Point Average}

Panel 1 of Figure 1 shows a comparison of mean academic performance, in terms of post-treatment grade point averages, conditional on pre-treatment grade point averages. Pre-treatment academic performance is closely related to post-treatment academic performance measures in both cases. There is a tendency for students to perform better in later years of the program, as the relationship in Panel 1 tends to reside about the dotted $x=y$ diagonal line. Students with highest pre-treatment GPAs perform worse, on average (i.e., the curve resides below the diagonal line); this necessarily follows from any variation will necessarily be downward among those who begin with a GPA near the maximum.

$<$ FIGURE $1>$

Table 3 reports differences in a regression framework to better determine the statistical significance of these relationships. The point estimates in this regression estimate therefore relate 
to how much GPA systematically deviates from what would be expected based on this baseline relationship.

On average, those with early exposure achieve about 0.02 lower grade point average, posttreatment (model 1). The difference concentrates on those with lower GPA (model 2); this result is invariant to multiple specifications (models 3 to 9), as should be expected given the random assignment. These and other patterns documented in the paper generally hold even when estimated separately in each cohort or each major. ${ }^{1}$ Panel 1 of Figure 1 presented these relationships in a quadratic specification to reveal any possible curvilinearity; we find not statistical evidence of curvilinearity whether including a full host of covariates as regressors (model 10) or otherwise.

Models (4) through (10) estimates heterogeneous treatment effects across observable demographic characteristics. Among observable demographic characteristics, females achieve highest grades on average, about 0.06 grade points higher (models 3 to 10); females are then unaffected by early exposure, i.e., the general effect of early exposure is -0.02, and females tend to outperform this by 0.02 (models $5,9,10)$.

Among observable demographic characteristics, students coming from outside the country have lowest GPAs, on average 0.08 grade points lower (models 3 to 10). Then they are also especially negatively affected by early exposure, in which case they fall another 0.12 grade points more than other individuals with early exposure (models 6,9, and 10). This means fall further from the general negative 0.02 grade points associated with early exposure, more generally.

By contrast, lower-income students benefit significantly from the early exposure, they are 0.09 more positively affected by the early exposure than other students (models 4, 9, and 10) - meaning they achieve about 0.07 grade points higher than they would otherwise, when subtracting the overall negative 0.02 general effect of early exposure.

\section{$<$ TABLE 3>}

\section{Graduation Rates}

A second measure of academic performance is the graduation rate. (Note: Graduation includes both failure and simply taking more than the usual period of time.) As shown in Panel 2 of Figure 1, the graduation rate converges towards 100 percent among higher-GPA students and becomes lower with with lower GPA. Levels of graduation are lower among those receiving early exposure.

Table 4 reports analysis of this relationship in a regression framework. The baseline relationship between graduation rates and pre-treatment GPA is concave (model 3 through 10). The overall

\footnotetext{
${ }^{1}$ For cohorts 2009 through 2012, we find the same relationship in relation to Early Job Treatment and Early Job $\times$ GPA. Signs are opposite for 2013, but those point estimates are highly imprecise with large standard errors. In relation to the different majors, the pattern holds over each major except for the case of Electrical Engineering. For the lone case of Electrical Engineering, the signs on Early Job Treatment and Early Job $\times$ GPA take opposite signs and are statistically significant at conventional levels. This may be a result of Electrical Engineering students mostly being drawn from a different (higher) GPA distribution, where the effects on lower-GPA students could be less salient.
} 
effect is to reduce graduation rates by about 2 percent (model 1 and 3). Therefore the incrementally earlier exposure causes a statistical negative effect on both measures of academic performance.

Among observable demographic characteristics, females have the highest graduation rates relative to the overall population among observable demographic groups (models 3 through 10), just as females were shown to have highest GPAs. In the case of both of these measures of academic performance, females are not significantly affected by the early exposure; they outperform roughly equally under early exposure.

Apart from females, in-state students (models 7, 9 and 10) and lower-income students (models 4, 9 and 10) outperform others in the early exposure treatment to the extent that their academic performance is not (negatively) affected by the early exposure. This is consistent with earlier GPA results, where both these groups outperform others in the early exposure - to the extent that in-state students are not (negatively) affected by the early exposure on academic performance and low-income students even tend to significantly increase their GPA with early exposure.

International students have (much) lower baseline graduation rates (models 3 to 10), again consistent with international students having lowest GPAs among observable demographic groups. However, whereas international students have lower GPAs and lower graduation rates, and the effect of early exposure on GPAs is negative, here we find the effect of early exposure on graduation rates is significantly positive. This seeming inconsistency in effects of early exposure on academic performance we interpret as related, first, to variation in graduation rates possibly acting on a very different margin than variation in GPA. Second, international students are a highly heterogeneous group and these treatment effects may relate to different students.

Despite older students having the same mean pre-treatment GPA as the population, in the later years of the program older students achieve slightly (-0.02) lower GPA and significantly (3 percent) lower graduation rates (models 3 to 7 ). The lower graduation rates appear to be mostly due to considerably lower graduation rates in early exposure. The estimated treatment effect on older students varies from model (8) to model (9) and is imprecisely estimated, but in both estimates older students differentially underperform other groups in the early exposure..

$<$ TABLE $4>$

\subsection{Early Exposure \& Academic Choices}

Apart from observing academic performance, we can also observe key academic choices in the data, including choice of (switching) majors and choice of (elective) courses.

\section{Choice of Major}

Panel 1 of Figure 2 plots the probability of individuals of different GPAs choosing to switch academic major in the post-treatment period. The probability of switching is higher in the group 
exposed to the earlier treatment. Models (1) and (2) in Table 5 present regression results confirming there is a 4 percent greater chance of switching majors with the earlier exposure. The overall likelihood of switching is decreasing with GPA. There is no statistical evidence of the treatment effect interacting with GPA.

$<$ FIGURE 2>

$<$ TABLE $5>$

Panels 2, 3, and 4 of Figure 2 stratify the probability of switching according to switching to a major inside of Engineering or to a major outside of Engineering. Particular sources and destinations of those switching majors are summarized in Table 6.

$<$ TABLE $6>$

We summarize these switches in our regression analysis in Table 5 in terms of whether switches are to subspecialities with higher or lower wages in relation to the starting major. (The rank order of wages is determined by mean wages observed in work term data.)

Reviewing Panels 2, 3, and 4 of Figure 2 suggests the greater probability of switching in early exposure is most clearly explained by switches to higher wage subfields. This difference is confirmed in the regression analysis reported in Table 5. Models (3) and (4) confirm the likelihood of switching to a higher-wage subspeciality in Engineering is roughly 2 or 3 percentage points higher, i.e., the coefficient on Early Job Treatment.

Whereas the general probability of switching declines with GPA level (model 1), the relationship if qualitatively different in relation to the treatment effect of early exposure. The treatment effect of early exposure and tendency to switch to higher-wage subfields is unrelated to GPA level (models 3). By contrast, it tends to be lower-GPA students who are more likely switch out of Engineering or into lower-wage subfields (models 5 and 7 ) Thus, the early exposure treatment operates in distinct ways from "usual" switching of majors.

Although the change in probability of switching to a higher-wage major is large and statistically significant for those receiving early exposure to work experience, there is little systematic heterogeneity across observable demographic characteristics. Point estimates on indicators of demographic subgroups interacted with the treatment effect are small and statistically insignificant. 


\section{Choice of Elective Courses}

Panel 1 of Figure 3 suggests that earlier exposure to professional work experience in Engineering also increases the share of courses that individuals choose to take in Engineering (rather than taking elective courses outside of the field). ${ }^{2}$ Another rough metric of a tendency to take more advanced and perhaps specialized courses is a tendency to take courses taught by tenure-track (rather than adjunct) faculty, as in Panel 2 of Figure 3.

$<$ FIGURE 3>

Table 7 reports patterns regarding the proportion of courses taken in Engineering in a regression framework. The analysis confirms a systematic tendency to take on average about a 2 percent greater number of Engineering courses when given the early exposure (model 1, 3, and 4). (This 2 percent is related to the total coursework, rather than in relation to just the elective courses over which individuals have a choice; the percentage of elective courses is, of course, higher.)

Once applying controls, we see that higher-GPA students tend to take a greater number of Engineering courses, all else being equal (models 3 to 9). (Foreign and older students take the greatest numbers of Engineering courses, generally speaking. Each takes 2 percent more Engineering courses on average than the wider population (see all models). International students, on average, take a greater number of Engineering courses than other students as a baseline (models 3 to 10); they then tend to take still more Engineering courses with the early exposure than other students, taking roughly 3 or 4 percent more Engineering courses in the early exposure.

\section{$<$ TABLE $7>$}

\subsection{Professional \& Post Graduation Outcomes}

\section{Engineering Employment \& Graduate School}

We proceed to examine whether the early exposure to work experience leads to systematic differences in career choices upon graduating, years after the initial exposure. The four panels of Figure 4 plot the probability of continuing in Engineering, either in graduate school or in employment, and the probability of pursuing employment outside of Engineering - all in relation to GPA - for earlier and later exposure to work experience.

Most conspicuous in these plots are differences in the likelihood of pursuing Engineering graduate studies. Table 8 reports these results in a regression framework. The likelihood of pursuing graduate school in Engineering is about 1 percent higher among those with the earlier exposure (model 1). More remarkably, the early exposure changes which particular individuals choose to

\footnotetext{
${ }^{2}$ The statistic presented reflects the proportion of total numbers of courses taken in Engineering during the post-treatment period, with variation coming from the subset of elective courses. Proportional variation among just elective courses will, therefore, be greater.
} 
pursue Engineering graduate school, as the choice to pursue Engineering graduate school become much more closely-tied to pre-treatment GPA in the early exposure (models (2) and (3)).

Further underlining a fundamental difference in how individuals sort into graduate school under the earlier exposure, the choice to pursue graduate school simply does not appear to be nearly as tied to pre-treatment GPA without the early exposure (model 2 and Panel 1 of Figure 4). In the case of later exposure to work experience, the slope relating the probability of Engineering graduate school and GPA is 0.01 (i.e., model 2 coefficient on GPA). In the ease of those with early exposure, this slope between the probability of Engineering graduate school and GPA becomes 0.11 (i.e., the earlier coefficient, plus model 2 coefficient on Early Job $\times$ GPA).

These stark effects on pursuing Engineering graduate school are not mirroredin any such effects related to non-Engineering graduate school (models 4, 5, and 6).

Whereas there is about 1 percent greater numbers of students overall who go to Engineering graduate school (model 1), there are about 1 percent fewer students joining Engineering employ-

ment (model 7). This is consistent with graduate school drawing from the pool of students who choose to pursue Engineering, more generally.

\section{$<$ FIGURE $4>$}

As regards observable demographic subgroups, truly striking first-order patterns relate to females and international students. females are 10 percent more likelyto not pursue Engineering employment. Despite these being relatively strong students and having a large treatment effect on GPA, the early exposure does nothing substantial not statistically significant to alter this tendency to leave Engineering.

International students are equally strikingly 10 percent more likely to pursue graduate school in Engineering than are US natives, as a baseline (models 2 and 3). They then are 10 percent more likely than the general population to pursue Engineering school among those receiving early exposure.

Older students are also more likely to pursue graduate school outside of Engineering when given the early exposure (models 5 and 6).

\section{$<$ TABLE $8>$}

\section{Quality of Employment}

We also observe measures providing an indication of quality and types of employment attained. A first is wage. We do not observe the wage after graduating; however, we do observe wages attained over the course of work terms. Figure 9 plots the wage attained over the course of the program (typically the highest wage is attained in the third and final work term), conditional on GPA, 
for early and later initial work terms. Figure 5 provides no immediate suggestion that having an earlier first work term has any systematic effect on wages, but only provides a clear indication that wages are higher among those with higher GPAs.

\section{$<$ FIGURE 5>}

Table 9 reports these relationships in a regression framework. Individuals assigned to early exposure early 0.20 dollars more, on average (model 1); however, this difference is estimated without precision. Wages attained increasing by about 2 dollars per pre-treatment grade point (model 1 to model 7 ).

Much of the 0.20 difference in wages of those in the early treatment, recorded in model (1), appears to be largely explained by increased wages of those with lower-income (model 2, 7, and 8). Earnings of lower-income individuals increase by 1.81 dollars (plus 0.01 for the general effect) when given the earlier exposure to Engineering work experience (model 2). This appears to more than make up for lower-income students attaining about a dollor lower wages when not given the early exposure (models 2, 7, and 8). There appear to be no other treatment effects of early exposure on wages attained.

To affirm this finding that lower-income students appear to make up lost ground-and more-on professional development when given an early exposure to professional Engineering experience, we matched data on employers after graduation from Dunn \& Bradstreet to employer data for individuals that we hand collected on Linkedin profiles. From matching these data sets, we could then determine whether treatment effects on lower-income students manifested in employment after graduation.

Models (9) and (10) report results where the dependent variable is replace with the $\log$ of employer revenues. We find that lower-income students join smaller firms as a baseline but, again, more than make up for this difference when given early professional experience. Consistent with the wage results, we find no other treatment effects beyond those on lower-income students.

The analysis also finds that international students attain much lower wages, on average (models 2 through 8). Wages are relatively higher when they are given earlier exposure, but the effect is slight and not statistical.

$<$ TABLE 9>

\section{$6 \quad$ Summary \& Discussion}

\subsection{Greater Costs \& Stresses with Early Labor Market Entry}

There are negative effects of early work experience on academic performance for lowest-GPA students and foreigners. These effects are small on average, but nonetheless systematic and statis- 
tically significant-providing clues regarding general tradeoffs of early entry to professional work experience in one's field.

On the one hand, these instances of lower academic performance are consistent with greater costs in dealing with challenges, disruptions, distractions and stresses of managing early entry to the professional labor market during the course of an undergraduate program. Lowest-GPA and international students may experience greater costs in struggling with academic work; and in the case of international students, there could also be language and adjustments within a context where they could have less support. Consistent with this interpretation, "in-state" local students - who presumably have greater local support and resources - experience not negative effect on academic performance whatsoever in the early exposure. It is also the case that low-GPA students and international students might be affected in a similar ways. International students have standardized college admission test scores that are 3.6 percentile points $($ s.e. $=1.3)$ lower than domestic students and the variation of these percentiles is $159 \%$ greater for international students (st.dev $=9.4$ for international versus 5.9 for domestic). We observe similar patterns in differences in data on high school GPAs. This is consistent with the large and diverse pool of international students including many that are weaker students, in ways that might not entirely be captured by the GPA measure. ${ }^{3}$

\section{$<$ TABLE $10>$}

It is also potentially the case that low-GPA and international students simply realize fewer benefits of early experience if they they are sytematically placed in lower-wage positions. To test this possibility, we begin with the observation that low-GPA and international students place in lower wage positions, as an endogenous outcome. To determine whether the quality of these endogenous placements will themselves produce lower academic performance, we test whether random assignment to lower-wage positions causes lower academic achievement.

We exploit the fact that students are assigned to advisors from the university as coaches as they enter the labor market. Crucially, these very same advisors are also in charge managing relationships with a subset of employers. Therefore students are randomly assigned to advisors who will have differential perspectives and knowledge of subsets of employers. We therefore exploit that assignment to a particular advisor will serve as an exogenous shifter of the type of job that someone gets. Consistent with this idea, regressing wages on advisor dummies dramatically increases variation explained beyond even what major and cohort fixed effects explains. Adjusted$R^{2}$ increases from 0.08 to 0.17 (with unadjusted $R^{2}$ being nearly the same values) from model (1) to model (2), as reported in Table 10. Remarkably, even controlling for cohort year and major differences, differences across different advisors are large and highly statistically significant.

We next proceed to analyzing whether exogenous differences in job assignment that are attributable to random assignment to advisors lead to observable differences in academic perfor-

\footnotetext{
${ }^{3}$ High school GPAs and standardized test scores appear to explain some degree of variation when added to earlier regressions.
} 
mance. Model (3) begins by regressing post-treatment GPA on the the wage received by the student in his or her first work term, along with major and cohort fixed effects in a simple OLS estimate, as a baseline. Re-estimating the model on the basis of just exogenous variation from random assignment shows the effect is tiny, at 0.005 grade points, and statistically zero (model

4). (The coefficient estimate is little changed in alternative specifications of interactions between treatment and GPA or inclusion of demographic variables.)

Repeating this analysis for graduation rates, as in models (5) and (6), shows that the estimated relationship between the graduation rate and first wage increases and remains statistically significant when estimating on the basis of variation created by random assignment. (Again, the coefficient estimate is little changed in alternative specifications of interactions between treatment and GPA or inclusion of demographic variables.) These results therefore demonstrate that the quality of initial work experience, at least as proxied by exogenous variation in wage, leads to variation in academic outcomes - years later. From these results, we conclude that some fraction of the poorer academic outcomes of low-GPA and international students could come from the tendency of matching to lower-quality positions, proxied by lower wages.

\subsection{Effects on Career "Sorting," "Engagement" \& "Retention" with Early Labor Market Entry}

If early entry to the professional labor market creates net costs for weakest lowest-GPA students, we might most naturally look for cases of benefits among the strongest or highest-GPA students. However, given that the strongest students already achieve close to the maximum GPA and maximum graduation rates possible, we simply cannot observe any possible upward variation in these same statistics. However, consistent with opposite (positive) effects seen on highest-GPA individuals, in contrast to outcomes of weakest students, those with highest-GPAs become about twice as likely to pursue graduate school in Engineering when given the early exposure to professional work experience.

More generally, the early exposure to experience in the field led to a much stronger positive relationship between student quality (proxied by pre-treatment GPA) and pursuing graduate school. Starkly, the relationship between the probability of going to Engineering graduate school and GPA was more than 10 times higher in the early exposure treatment. This could be consistent with learning more of opportunities and interests early in the program, perhaps when it is easier to then either find the motivation or the ability to focus on areas of greatest interests.

Consistent with this idea of greater sorting and perhaps engagement with one's areas of interest as a result of early exposure to professional labor market experience, is the increased incidence of switching majors associated with this. Perhaps more important than increasing switching of majors per se is that the nature of switching associated with early exposure. While switching of major, in general, is often associated with lower-GPA students and switching to lower-wage 
subfields of engineering, switching associated with early exposure is related to different kinds of switching altogether. Early exposure mostly leads to systematic switching to higher-wage subfields of Engineering. Therefore, apart from the above graduate school result related to skills, here we have choices better related to wages and market opportunity. Thus, the results begin to paint a broader picture of more systematic and informed sorting in relation to economic variables - even prior to graduating.

Inasmuch as these effects might be related, too, to greater engagement, interest and possibly to motivation in the field apart from just greater information and associated sorting - we find that individuals assigned to earlier exposure also systematically chose to take a greater number of Engineering courses.

\subsection{Human Capital Development with Early Labor Market Entry}

Where we observe most conspicuous evidence of increased GPAs and graduation rates with early exposure is in the case of lower-income students (i.e., those receiving 50th percentile or greater financial aid support). Of course, the positive effects on lower-income students immediately raises the possibility that early paid experience could be from mitigating financial pressures.

However, there are reasons to suspect a richer and more nuanced explanation in these data related to supplementing human capital of certain kinds. To consider this, first note that relative to the entire population of students, lower-income students show themselves to be higher-quality students, on average, by pre-treatment GPA. When given the early exposure, these students then proceed to outperform their peers in post-treatment GPA, conditional on their pre-treatment GPA. Thus, lower-income students become even better at learning and succeeding in the classroom when given early exposure. This fact requires some explanation.

What makes lower-income students become even stronger students when given early exposure? We speculate that one possibility is that early exposure differentially benefits those whose direct family members and social network might include fewer mentors with prior experience in the profession. If this were the case, a relatively naive young person with little knowledge of the profession could differentially benefit from early exposure, substituting from a lack of social and professional ties and previous knowledge. This case could be interpreted as conveying greater knowledge of Engineering practice and enhanced related academic performance.

Consistent with this explanation, not only do low-income students with early exposure to professional work experience in Engineering obtain higher grades in the post-treatment period; they also realize higher wages and join larger firms than they would otherwise. This could relate to accelerated academic development. Early exposure to the labor market could also expand human capital in the sense of growing professional networks or reputation. 


\subsection{Other Questions}

Females are a highly notable subgroup of students in this study. They begin the program with higher-GPAs; they generally increase their academic performance relative to peers over the course of the program. Most relevant to this study, they tend to accelerate their academic performance even more when they gain early exposure to the professional labor market. However, despite this differential success of females, conditional on pre-treatment GPA, in response to early exposure in academic performance - we see little corresponding statistically differential outcomes in other observed dimensions in relation to the early labor market exposure. Most strikingly, the intervention does little to alter the 10 percent difference between males and females likelihood of pursuing Engineering employment, upon graduating.

The analysis also uncovered an array of striking results related to international students beyond those summarized just in Section 6.1. On the one hand, the mean academic performance and response to early work experience suggests this group may contain weaker students. On the other hand, international students, on average, take more Engineering courses and 10\% more go to Engineering graduate school in the early exposure, on top of a baseline $10 \%$ more going to graduate school. Therefore, this group appears to include both weaker and stronger Engineering students, and we might expect the mean estimates reported in the earlier analysis is averaging possibly countervailing effects across different types of students captured by the Foreign indicator variable.

\section{Conclusion}

How can higher education institutions best develop and prepare skilled workers? The prevailing model of higher education involves an abrupt transition from "theory to practice" (i.e., from fulltime formal academic training to entry to full-time work upon graduation). To better understand possible tradeoffs with this dominant institutional approach, we studied the effects of randomly assigning Engineering majors from a top-40 U.S. program to incrementally earlier exposure to professional labor market experience, drawing observations over multiple years.

We found the earlier exposure caused systematic differences across a wide range of observables - and for years following initial the exposure. We found differences in both academic outcomes (GPA, graduation rates, choice of major, and choice of courses) and professional and career outcomes (graduate school, employment within and outside Engineering, wages attained, and size of employer joined).

Given the inherent link between theory and practice in Engineering and Applied Science, we expected to find some tension or possible complementarity between academics and practical professional experience in the human capital development process. A preliminary reading of the results might first indicate a tension between the two as, on average, post-treatment academic outcomes 
worsen with early exposure - at least for lowest-GPA students and international students. The evidence is consistent with more significant stresses and costs from early entry to professional work.

The broader patterns across the wider population, however, indicate more nuanced effects than just a tension or complementarity between theory and practice. Engineering students exposed to professional work experience choose to take a higher number of Engineering courses, more often switch to higher-income subfields, and more likely to pursue Engineering graduate if they are inherently stronger students. We interpret these patterns as consistent with more informed career sorting and self-selection (before graduation) and greater engagement in Engineering.

The early exposure to work experience causes especially greater academic and professional outcomes for lower-income students, leading to higher grades, higher wages, and a greater tendency to join larger firms upon graduating. These patterns are consistent with relieving financial stresses or providing more knowledge or professional networks in the profession. 


\section{References}

American Association of Colleges \& Universities (2013). "It Takes More Than a Major: Employer Priorities for College Learning and Student Success." Accessed IO January 2019 at https://www.aacu.org/sites/default/files/files/LEAP/20I3_EmployerSurvey.pdf.

American Association of Colleges \& Universities (2015). "Falling short? College Learning and Career Success." Accessed IO January 2019 at https://www.aacu.org/sites/default/files/files/LEAP/20I5employerstudentsurvey.pdf.

Abadie, Alberto, Susan Athey, Guido W. Imbens, and Jeffrey M. Wooldridge. Finite population causal standard errors. No. w20325. National Bureau of Economic Research, 2014.

Angrist, Joshua, Stacey Chen (20II). "Schooling and the Vietnam-Era GI Bill: Evidence from the Draft Lottery." American Economic Journal: Applied Economics 3: 96-II9.

Arrow, Kenneth J., and William M. Capron. "Dynamic Shortages and Price Rises: The Engineer-Scientist Case." The Quarterly Journal of Economics 73.2 (1959): 292-308.

Athey, Susan, and Guido W. Imbens. "The Econometrics of Randomized Experimentsa." In Handbook of Economic Field Experiments, vol. I, pp. 73-I40. North-Holland, 2017.

Atkinson, Richard C. (1990) "Supply and Demand for Scientists and Engineers: A National Crisis in the Making." Science 248.4954: 425-432.

Ashworth, Jared, Joseph Hotz, Arnaud Maurel, Tyler Ransom. (20I7) "Changes across Cohorts in Wage Returns to Schooling and Early work Experiences" Working Paper.

Becker, G.S., (1994). Human capital revisited. In Human Capital: A Theoretical and Empirical Analysis with Special Reference to Education (3rd Edition) (pp. 15-28). The University of Chicago press.

Bettinger, Eric, Bridget Long, Philip Oreopoulos Lisa Sanbonmatsu (2009). "The Role of Simplification and Information in College Decisions: Results from the H\&R Block FAFSA Experiment," Working Paper I536I (Cambridge, Mass.: National Bureau of Economic Research, September 2009).

Blair, Benjamin F., Meghan Millea, and Joshua Hammer. (2004) "The Impact of Cooperative Education on Academic Performance and Compensation of Engineering Majors." Journal of Engineering Education 93.4: $333-338$.

Bleemer, Zachary, and Basit Zafar. (20I8) "Intended College Attendance: Evidence from an Experiment on College Returns and Costs." Journal of Public Economics I57 (20I8): I84-2II.

Blundell, Richard, Lorraine Dearden, Costas Meghir, and Barbara Sianesi. (I999) "Human capital investment: the returns from education and training to the individual, the firm and the economy." Fiscal Studies 20, no. I: I-23.

Bowen, Howard. (20I8). Investment in Learning: The Individual and Social Value of American Higher Education. Routledge.

Brophy, S., Klein, S., Portsmore, M. and Rogers, C., (2008). Advancing Engineering Education in P-I2 classrooms. Journal of Engineering Education, 97(3), pp.369-387.

Card, David. "Using Geographic Variation in College Proximity to Estimate the Return to Schooling," in Aspects of Labor Market Behaviour: Essays in Honour of John Vanderkamp, edited by Louis N. 
Christofides, E. Kenneth Grant and Robert Swidinsky, (Toronto: University of Toronto Press, 1995), pp. $20 \mathrm{I}-222$.

Casner-Lotto, Jill, and Linda Barrington. Are They Really Ready to Work? Employers' Perspectives on the Basic Knowledge and Applied Skills of New Entrants to the 2Ist Century US Workforce. Partnership for 2Ist Century Skills. I Massachusetts Avenue NW Suite 700, Washington, DC 2000I, 2006.

Chen, Xianglei and Matthew Soldner (2013). "STEM Attrition: College Students' Paths into and out of STEM Fields. Statistical Analysis Report. NCES 20I4-00I." National Center for Education Statistics.

Crawley, Edward, Johan Malmqvist, Soren Ostlund, and Doris Brodeur. (2007). Rethinking engineering education. The CDIO Approach, 302, 60-62.

De la Croix, David, Matthias Doepke, and Joel Mokyr. (20I7) "Clans, Guilds, and Markets: Apprenticeship Institutions and Growth in the Preindustrial Economy." The Quarterly Journal of Economics I33.I: I-70.

De Munck, B., Kaplan, S. L., \& Soly, H. (Eds.). (2007). Learning on the Shop Floor: Historical Perspectives on Apprenticeship (Vol. I2). Berghahn Books. Chicago.

Dym, Clive L., Alice M. Agogino, Ozgur Eris, Daniel D. Frey, and Larry J. Leifer. "Engineering design thinking, teaching, and learning." Journal of Engineering Education 94, no. I (2005): I03-I2O.

Eyler, Janet. (2009) "The power of experiential education." Liberal Education 95.4: 24-3I.

Fayer, Stella, Alan Lacey, and Audrey Watson. "STEM occupations: Past, present, and future." U.S. Bureau of Labor Statistics: Spotlight on Statistics (2017).

Felder, Richard M. (I982). Does Engineering Education Have Anything to Do with Either One?: Toward a Systems Approach to Training Engineers. School of Engineering, North Carolina State University at Raleigh, I982.

Felder, Richard M., Donald R. Woods, James E. Stice, and Armando Rugarcia. "The future of engineering education II. Teaching methods that work." Chemical Engineering Education 34, no. I (2000): 26-39.

Felder, Richard, and Linda K. Silverman. "Learning and Teaching Styles in Engineering Rducation." Engineering Education 78.7 (1988): 674-68I.

Gardner, Philip D., David C. Nixon, and Garth Motschenbacker. (1992) "Starting Salary Outcomes of Cooperative Education Graduates." Journal of Cooperative Education 27.3: I6-26.

Goolsbee, Austan. (1998) "Does Government R\&D Policy Mainly Benefit Scientists and Engineers?," American Economic Review, vol. 88(2), pages 298-302.

Grayson, Lawrence P. (1977) "A Brief History of Engineering Education in the United States." Engineering Education 68.3: 246-64.

Griliches, Z. (I98I). "Schooling Interruption, Work While in School and the Returns from Schooling”. In Unemployment (pp. I63-I75). Palgrave Macmillan, London.

Heckman, J. J., and Rubinstein, Y. (200I). "The Importance of Noncognitive Skills: Lessons from the GED Testing Program.” American Economic Review, 9I(2), I45-I49.

Freeman, Richard. (2006). "Does Globalization of the Scientific/Engineering Workforce Threaten US Economic Leadership?." Innovation Policy and the Economy 6: I23-I57. 
Jeffrey Froyd, Diane Hurtado, Magdalini Lagoudas, Sandra Nite, Margaret Hobson, Jacqueline Hodge, Joy Monroe (20I2). "Increasing Access to Engineering." 20I2 Frontiers in Education Conference Proceedings.

Jørgensen, Ulrik. (2007). "Historical Accounts of Engineering Education." In Rethinking Engineering Education (pp. 216-240). Springer, Boston, MA.

Karataş, F. Ö., G. M. Bodner, and Suat Unal. "First-year engineering students' views of the nature of engineering: implications for engineering programmes." European Journal of Engineering Education 4I, no. I (20I6): I-22.

Kelly, Terrence K., William Butz, Stephen Carroll, David Adamson, and Gabrielle Bloom. (2004). The US Scientific and Technical Workforce: Improving Data for Decision-Making. RAND Corporation. Santa Monica. CA.

Kerr, William. (20I3). US High-Skilled Immigration, Innovation, and Entrepreneurship: Empirical Approaches and Evidence. No. wi9377. National Bureau of Economic Research.

Light, A. (1995). The Effects of Interrupted Schooling on Wages. Journal of Human Resources, 472-502.

Light, Audrey. (1998). "Estimating Returns to Schooling: When Does the Career Begin?" Economics of Education Review I7, no. I: 3I-45.

Light, Audrey, and Manuelita Ureta. (I995) "Early-career work experience and gender wage differentials." Journal of Labor Economics I3.I: I2I-I54.

Light, A. (200I). "In-school Work Experience and the Returns to Schooling. Journal of Labor Economics, I9(I), 65-93.

Lindenmeyer, Ray. "A Comparison Study of the Academic Progress of the Cooperative and the Four-year Student." Journal of Cooperative Education 3.2 (1967): 8-I8.

Luckner, John L., and Reldan S. Nadler. (1997). Processing the Experience: Strategies to Enhance and Generalize Learning. Kendall/Hunt Publishing Company, 4050 Westmark Drive, Dubuque, IA 52002.

Maloney, William F., and Felipe Valencia Caicedo. (20I6). "The Persistence of (Subnational) Fortune." The Economic Journal I26.598: 2363-240I.

Manski, Charles F. (I993) "Adolescent Econometricians: How do Youth Infer the Returns to Schooling?." Studies of Supply and Demand in Higher Education. University of Chicago Press, 43-60.

Murphy, Kevin M., Andrei Shleifer, and Robert W. Vishny. (I99I). "The Allocation of Talent: Implications for Growth." The Quarterly Journal of Economics. I06.2: 503-530.

National Research Council. (20II). Successful K-I2 STEM education: Identifying effective approaches in science, technology, Engineering, and mathematics. National Academies Press, 20II.

Neal, Derek. (1995). "Industry-specific human capital: Evidence from displaced workers." Journal of labor Economics I3.4: 653-677.

Neumark, David, and Donna Rothstein. (2006) "School-to-Career Programs and Transitions to Employment and Higher Education." Economics of Education Review 25.4: 374-393.

Oreopoulos, Philip, and Uros Petronijevic. "Making College Worth It: A Review of the Returns to Higher Education." The Future of Children (2013): 4I-65. 
National Academy of Engineering. (2005). Educating the Engineer of 2020: Adapting Engineering Education to the New Century. Washington, DC: The National Academies Press.

Reingold, D. (1999). "Social networks and the employment problem of the Urban Poor." Urban Studies 36(II).

Roberts, J. (2015). Experiential Education in the College Context. New York: Routledge Press.

Romer, Paul M. (2000) "Should the Government Subsidize Supply or Demand in the Market for Scientists and Engineers?." Innovation Policy and the Economy I: 22I-252.

Rosenberg, Nathan, and Richard R. Nelson. "American universities and technical advance in industry." Research Policy 23.3 (1994): 323-348.

Ryoo, Jaewoo, and Sherwin Rosen. (2004) "The Engineering Labor Market." Journal of Political Economy II2.SI: SiIO-Si40.

Schultz, Theodore W. (I96I) "Investment in Human Capital." American Economic Review 5I.I: I-I7.

Seely, Bruce. (1993). "Research, Engineering, and Science in American Engineering Colleges: I9001960." Technology and Culture. 34.2: 344-386.

Seely, Bruce E. (1999). "The 'Imbalance' of Theory and Practice in American Engineering Education: Reforms and Changes, I920-1980." Icon 40-63.

Shu, Pian. (20I6) "Innovating in Science and Engineering or 'Cashing In' on Wall Street? Evidence on Elite STEM Talent." Harvard Business School Working Paper, No. I6-067.

Spence, Michael. (1973). "Job Market Signaling," The Quarterly Journal of Economics. Vol. 87:3 (August): 355-374.

Shuman, Larry, Mary Besterfield-Sacre, Jack McGourty. (2005) "The ABET “professional skills" - Can they be taught? Can they be assessed?." Journal of Engineering Education. 94.I (2005): 4I-55.

Stinebrickner, Ralph, and Todd R. Stinebrickner. "Working during school and academic performance." Journal of Labor Economics 2I.2 (2003): 473-49I.

Reynolds, Terry S. (1992). "The Education of Engineers in America before the Morrill Act of I862." History of Education Quarterly 32.4 (1992): 459-482.

Talgar, Cigdem P., Laura A. Wankel, Jennifer Lehmann, Mary English, Kaleena Seeley, Jillian Scheer, Brooke Hoger, Kimberly Irmiter, Susan A. Ambrose, and Yevgeniya V. Zastavker. (20I7). "Student assessed integrated learning: SAILing to a holistic design of holistic engineering education." In IEEE Frontiers in Education Conference Proceedings, pp. I-5.

Thiel, Glenn, and Nell Hartley. (1997). "Cooperative Education: A Natural Synergy between Business and Academia." SAM Advanced Management Journal. 62.3: I9.

US News and World Report (2015). "Understand the Differences Between a Co-op, Internship." https://www.usnews.com/education/best-colleges/articles/20I5/03/3I/understand-the-differences-betweena-co-op-internship

Van Gyn, Geraldine. (1997). "Investigating the Educational Benefits of Cooperative Education: A Longitudinal Study." Journal of Cooperative Education 32.2: 70-85.

Wessels, Walter, and Gerald Pumphrey. "The Effects of Cooperative Education on Job-Search Time, Quality of Job Placement and Advancement." Journal of Cooperative Education. 3I (I995): 42-52. 
White House Press Release (20I5). "President Obama Announces Over \$240 Million in New STEM Commitments at the 2015 White House Science Fair."

White House Press Release (2017). "President Trump Signs Memorandum for STEM Education Funding."

Young, Alwyn (20I8). "Channeling fisher: Randomization tests and the statistical insignificance of 

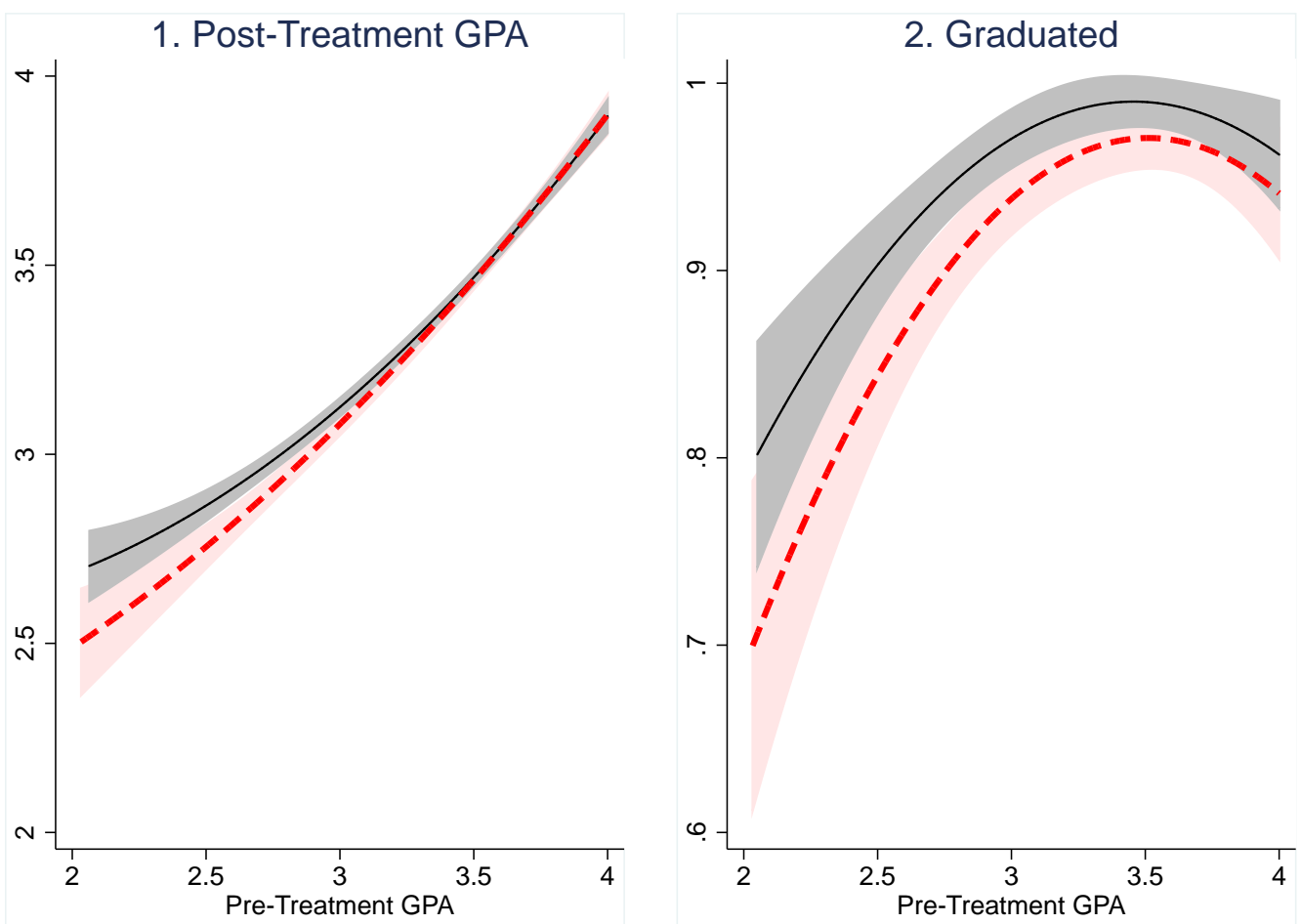

3

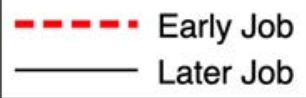

Figure I Early Work Exposure and Academic Performance: Grade Point Average (GPA) \& Graduation Rates

Note. This figure plots the quadratic relationship between post-treatment GPA and pre-treatment GPA, stratified by earlier and later exposure to first professional work experience, along with 95\% confidence intervals. All curves indicate that pre-treatment GPA early in the program predicts academic performance later in the program. Mean academic performance is slightly lower for those who enter the workforce earlier, particularly for those with lowest-GPAs. 

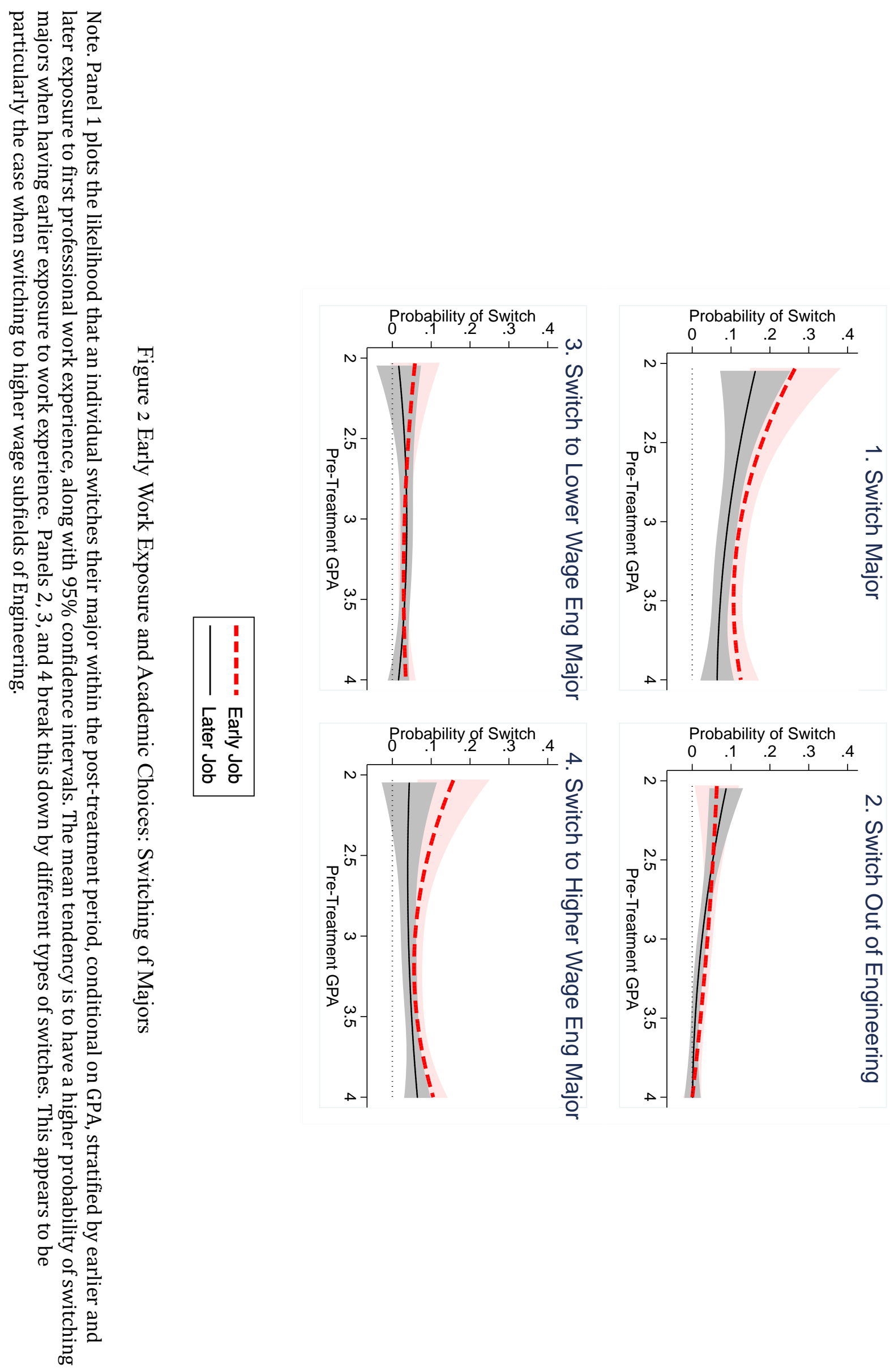


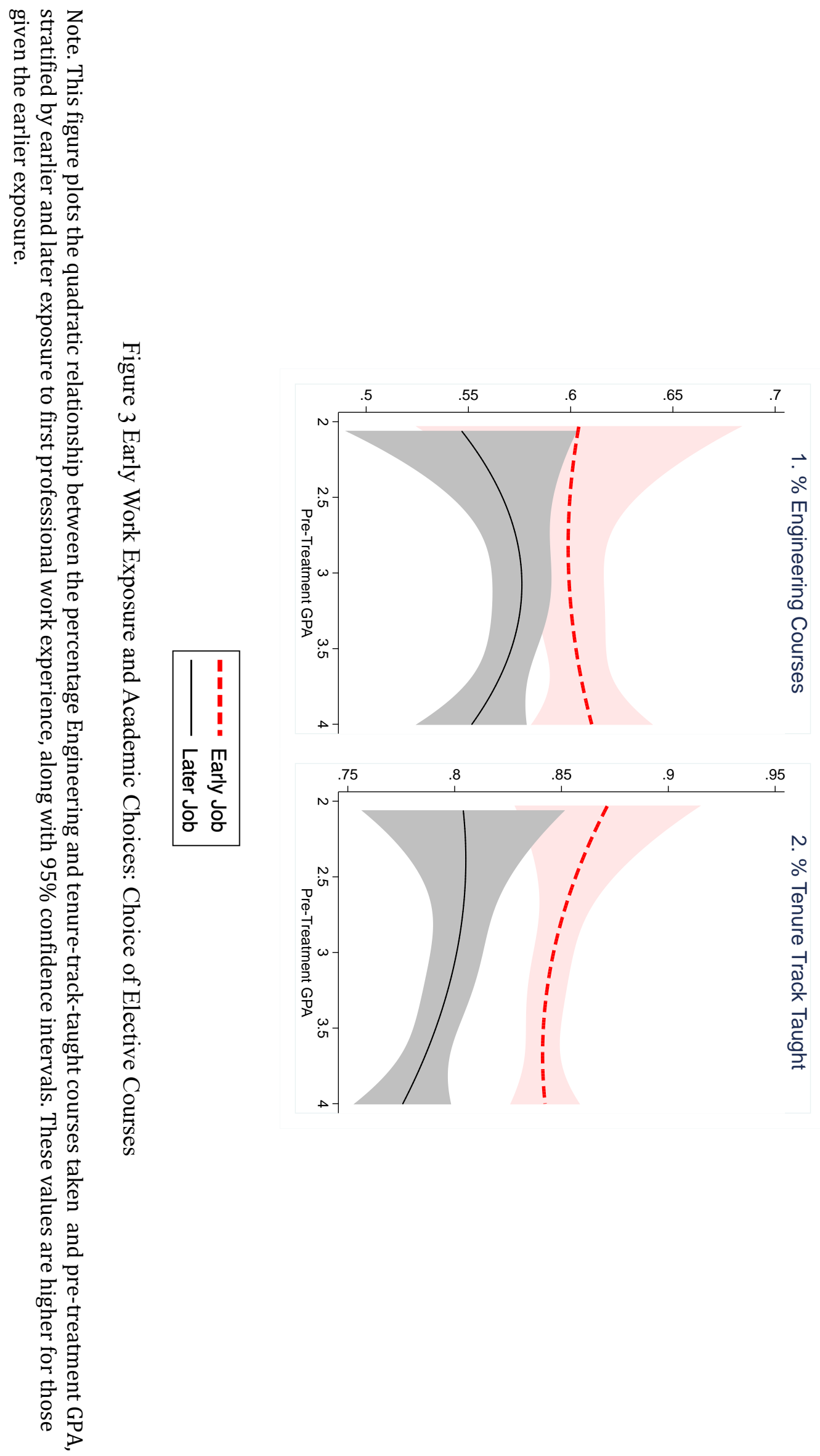




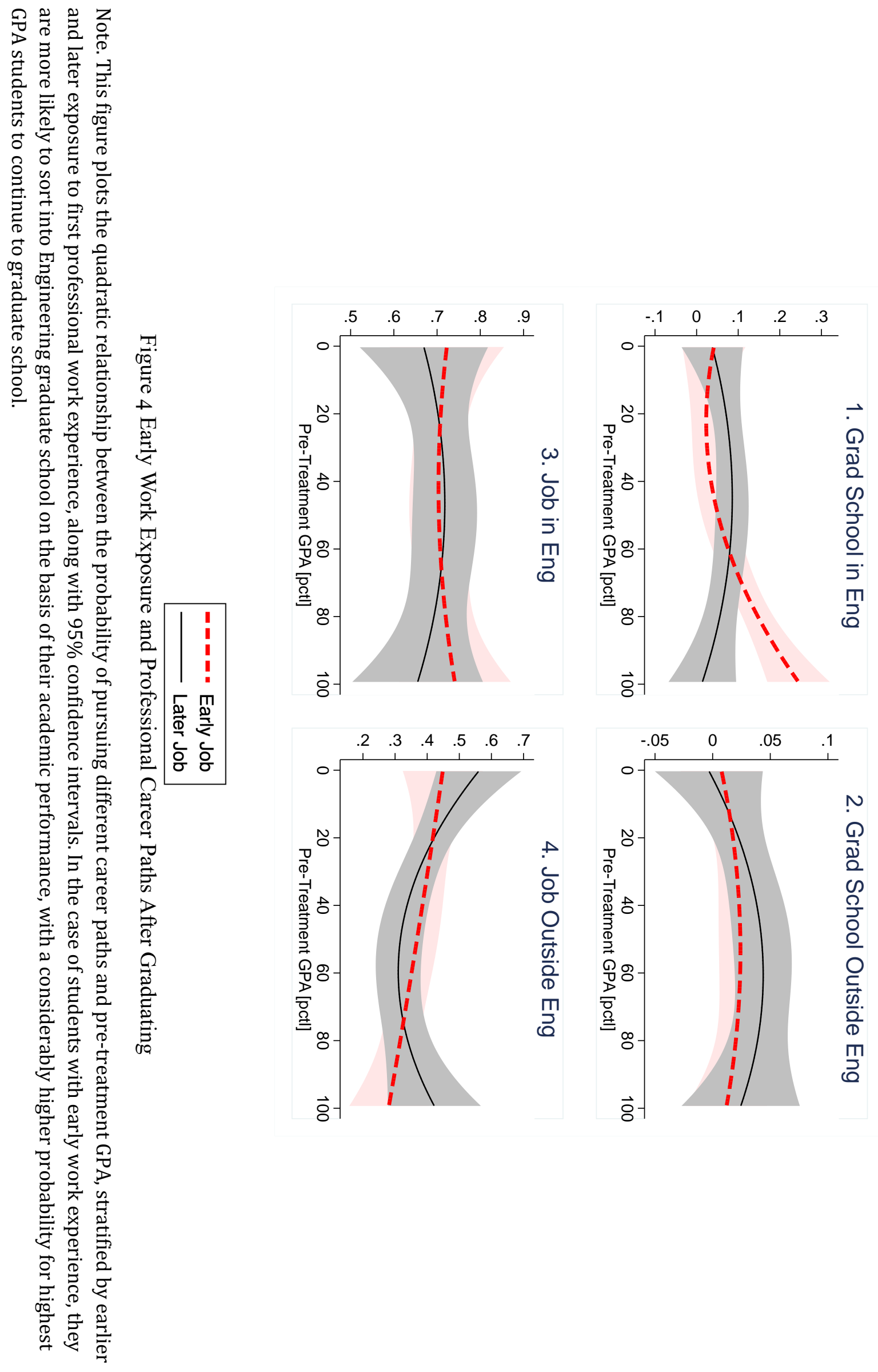




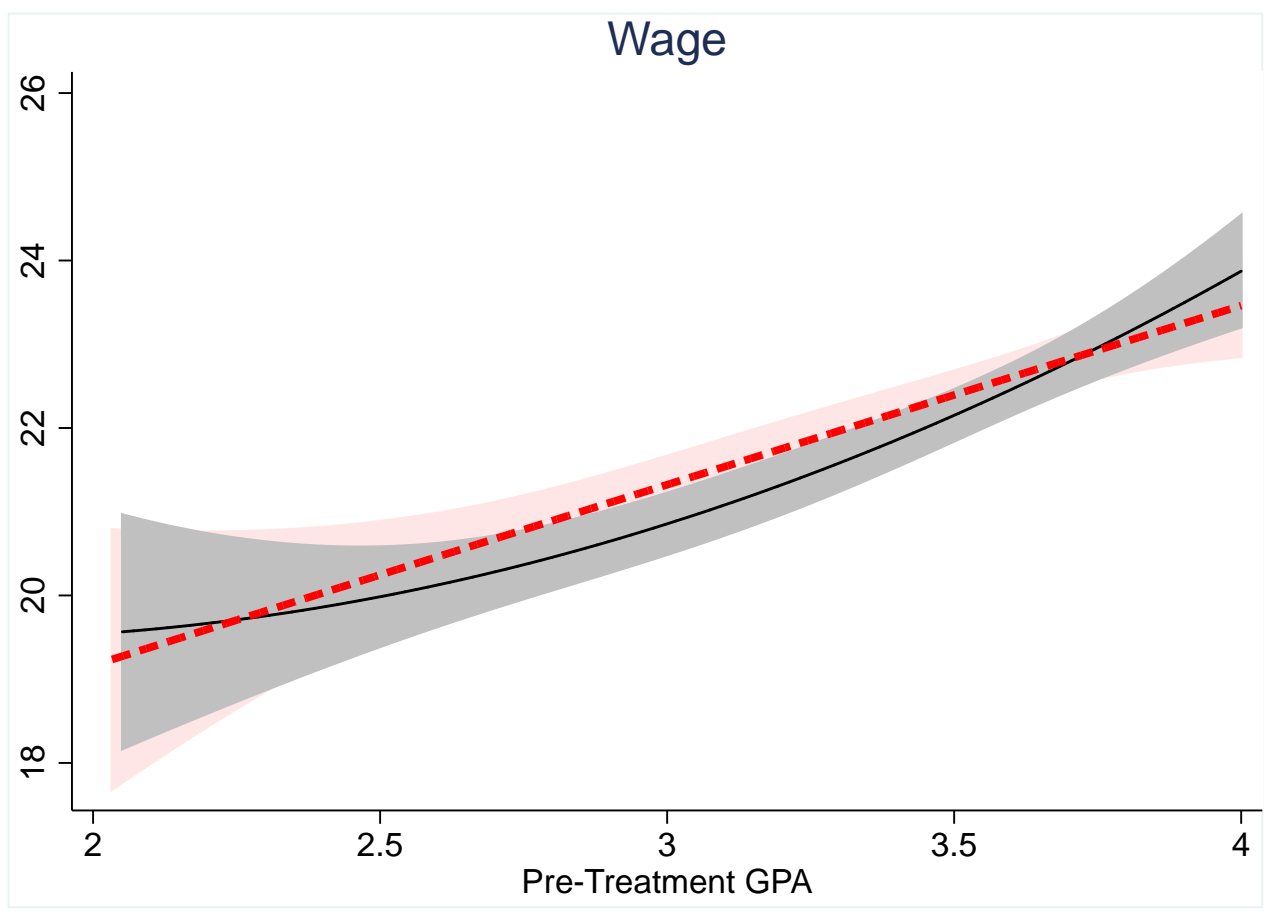

$-=-\boldsymbol{- n}$ Early Job
Later Job

Figure 5 Highest Hourly Wage Attained: Early (red dashed) and Late (grey solid) Exposure to Professional Work

Note. This figure plots the quadratic relationship between the highest wage attained on work term while in the progam and pre-treatment GPA, stratified by earlier and later exposure to first professional work experience, along with 95\% confidence intervals. The highest wage attained is typically in the third and final work term. Wage increases with GPA, but there is not clear relationship with earlier or later exposure. 
Table I Description of Main Variables in the Analysis

\begin{tabular}{|c|c|c|c|c|c|}
\hline Variable: & Mean & Std. Dev. & Min & Max & Definition \\
\hline Grade Point Average & 3.36 & 0.45 & 0.18 & 4.25 & $\begin{array}{l}\text { Grade Point Average from 4th Academic term } \\
\text { to graduation }\end{array}$ \\
\hline Graduated & 0.94 & 0.24 & 0 & 1 & $\begin{array}{l}\text { Indicator switched to one if graduated within } \\
\text { observation period }\end{array}$ \\
\hline Switched Major & 0.01 & 0.09 & 0 & 1 & $\begin{array}{l}\text { Indicator for change in major from previously } \\
\text { declared major in post-treatment period }\end{array}$ \\
\hline \multirow[t]{2}{*}{$\begin{array}{l}\text { Percent Engineering } \\
\text { Courses }\end{array}$} & 0.58 & 0.14 & 0 & 1 & $\begin{array}{l}\text { Total share of courses in Post-Treatment } \\
\text { period taken from school of Engineering }\end{array}$ \\
\hline & 0.56 & 0.50 & 0 & 1 & \\
\hline $\begin{array}{l}\text { Stay in Engineering } \\
\text { at Grad }\end{array}$ & & & & & $\begin{array}{l}\text { Indicator for Engineering employment or } \\
\text { graduate school }\end{array}$ \\
\hline $\begin{array}{l}\text { Employer Size, } \\
\ln \text { (Revenues) }\end{array}$ & 5.24 & 7.36 & 0.00 & 22.80 & $\begin{array}{l}\text { Log of annual revenues of first employer upon } \\
\text { graduating }\end{array}$ \\
\hline Wage & 21.93 & 4.46 & 0.00 & 46.00 & $\begin{array}{l}\text { Highest wage attained on work terms } \\
\text { (typically final term) }\end{array}$ \\
\hline Pre-Treatment GPA & 3.33 & 0.45 & 1.48 & 4.00 & Grade Point Average up to 3rd Academic term \\
\hline Lower-Income & 0.05 & 0.23 & 0 & 1 & $\begin{array}{l}\text { Indicator for greater than 50th percentile } \\
\text { financial aid }\end{array}$ \\
\hline Female & 0.21 & 0.41 & 0 & 1 & Indicator for sex \\
\hline International & & & & & Indicator for non-citizen \\
\hline In-State & 0.31 & 0.47 & 0 & 1 & Indicator for permanent address in same state \\
\hline Older & 0.29 & 0.45 & 0 & 1 & $\begin{array}{l}\text { More than one year older than modal age in a } \\
\text { given year }\end{array}$ \\
\hline Early Job & 0.54 & 0.50 & 0 & 1 & $\begin{array}{l}\text { Indicator for assignment to work term } \\
\text { beginning in second year (rather than third } \\
\text { year) }\end{array}$ \\
\hline
\end{tabular}

Note. No. obs $=1,787$ individuals. The main variables in the analysis include a set of measure of academic outcomes and choices, along with professional outcomes and choices-summarizing outcomes in years following the initial exposure. Apart from the treatment variable, other regressors related to academic and demographic individual covariates. 
Table 2 Balance of Observable Characteristics across Early and Late Exposure Groups

\begin{tabular}{|c|c|c|c|}
\hline \multirow[b]{3}{*}{ Initial work term } & \multicolumn{2}{|c|}{ Mean } & \multirow[b]{2}{*}{ s.e. diff. } \\
\hline & Early Group & Late Group & \\
\hline & & & \\
\hline Age at matriculation & 18.34 & 18.34 & 0.03 \\
\hline Female & 0.23 & 0.21 & 0.02 \\
\hline International & 0.06 & 0.09 & 0.01 \\
\hline Financial aid award & 17124.99 & 17440.45 & 490.67 \\
\hline \multicolumn{4}{|l|}{ Pre-Treatment Academics } \\
\hline High-school GPA & 4.00 & 4.00 & 0.02 \\
\hline Percentile on standardized tests & 0.86 & 0.86 & 0.00 \\
\hline Cumulative GPA & 3.36 & 3.37 & 0.02 \\
\hline \# credits completed & 53.22 & 53.29 & 0.14 \\
\hline Enrollment per class & 53.72 & 54.29 & 0.65 \\
\hline$\%$ courses in Engineering & 0.31 & 0.29 & 0.00 \\
\hline$\%$ courses with tenure-track & 0.81 & 0.79 & 0.01 \\
\hline \multicolumn{4}{|l|}{ First Work Term } \\
\hline Work term in U.S. & 0.97 & 0.98 & 0.01 \\
\hline Hourly wage & 18.79 & 18.69 & 0.25 \\
\hline Engineering job & 0.96 & 0.97 & 0.01 \\
\hline \multicolumn{4}{|l|}{ Courses Offered Post-Treatment } \\
\hline Number of courses offered & 1038.13 & 1084.25 & 23.54 \\
\hline$\%$ engineering courses offered & 0.15 & 0.16 & 12.70 \\
\hline$\%$ courses with tenure-track & 0.82 & 0.80 & 108.81 \\
\hline Enrollment per class & 23.46 & 23.87 & 0.40 \\
\hline
\end{tabular}

Note. No. obs $=1,787$ individuals. Groups receiving relatively early and late first exposure to the work experience are similar in their own characteristics, receive identical pre-treatment programs, and have access to the same academic and professional opportunities in the post-treatment period. They take a statistically identical number work terms in total (just under three, on average) and start and end the program at the same time. The main difference is only when they take their first work term. 
Table 3 Effect of Incrementally Earlier Professional Labor Market Experience on GPA

\begin{tabular}{|c|c|c|c|c|c|c|c|c|c|c|}
\hline \multirow{2}{*}{$\begin{array}{r}\text { Dep. Var.: } \\
\text { Model: }\end{array}$} & \multicolumn{10}{|c|}{ Post-Treatment Grade Point Average (GPA) } \\
\hline & (1) & (2) & (3) & (4) & (5) & (6) & (7) & (8) & (9) & (10) \\
\hline \multicolumn{11}{|l|}{ Treatment Effects } \\
\hline Early Job Treatment & $\begin{array}{l}-0.02 \\
(0.02)\end{array}$ & $\begin{array}{l}-0.24^{*} \\
(0.14)\end{array}$ & $\begin{array}{l}-0.27^{*} \\
(0.14)\end{array}$ & $\begin{array}{l}-0.25^{*} \\
(0.14)\end{array}$ & $\begin{array}{l}-0.26^{*} \\
(0.14)\end{array}$ & $\begin{array}{l}-0.24^{*} \\
(0.14)\end{array}$ & $\begin{array}{l}-0.27^{*} \\
(0.14)\end{array}$ & $\begin{array}{l}-0.27^{*} \\
(0.14)\end{array}$ & $\begin{array}{l}-0.23 \\
(0.14)\end{array}$ & $\begin{array}{l}-0.84 \\
(0.85)\end{array}$ \\
\hline Early Job $\times G P A$ & & $\begin{array}{l}0.07^{*} \\
(0.04)\end{array}$ & $\begin{array}{l}0.07 * \\
(0.04)\end{array}$ & $\begin{array}{l}0.07^{*} \\
(0.04)\end{array}$ & $\begin{array}{l}0.07^{*} \\
(0.04)\end{array}$ & $\begin{array}{l}0.07^{*} \\
(0.04)\end{array}$ & $\begin{array}{l}0.07^{*} \\
(0.04)\end{array}$ & $\begin{array}{l}0.07 * \\
(0.04)\end{array}$ & $\begin{array}{c}0.06 \\
(0.04)\end{array}$ & $\begin{array}{c}0.46 \\
(0.51)\end{array}$ \\
\hline Early Job $\times G P A^{\wedge} 2$ & & & & & & & & & & $\begin{array}{l}-0.06 \\
(0.08)\end{array}$ \\
\hline Early Job $\times$ Low Income & & & & $\begin{array}{l}0.09^{*} \\
(0.05)\end{array}$ & & & & & $\begin{array}{l}0.09^{*} \\
(0.05)\end{array}$ & $\begin{array}{l}0.10^{* *} \\
(0.05)\end{array}$ \\
\hline Early Job $\times$ Female & & & & & $\begin{array}{c}0.02 \\
(0.03)\end{array}$ & & & & $\begin{array}{c}0.02 \\
(0.03)\end{array}$ & $\begin{array}{c}0.02 \\
(0.03)\end{array}$ \\
\hline Early Job $\times$ Foreign & & & & & & $\begin{array}{l}-0.12 * \\
(0.07)\end{array}$ & & & $\begin{array}{l}-0.12 * \\
(0.07)\end{array}$ & $\begin{array}{l}-0.11^{*} \\
(0.07)\end{array}$ \\
\hline Early Job $\times$ In-State & & & & & & & $\begin{array}{c}0.03 \\
(0.03)\end{array}$ & & $\begin{array}{c}0.02 \\
(0.03)\end{array}$ & $\begin{array}{c}0.02 \\
(0.03)\end{array}$ \\
\hline Early Job $\times$ Older & & & & & & & & $\begin{array}{c}0.00 \\
(0.03)\end{array}$ & $\begin{array}{c}0.01 \\
(0.03)\end{array}$ & $\begin{array}{c}0.01 \\
(0.03)\end{array}$ \\
\hline \multicolumn{11}{|c|}{ Academic Characteristics } \\
\hline Pre-Treatment GPA & $\begin{array}{l}0.73 * * * \\
(0.02)\end{array}$ & $\begin{array}{l}0.69 * * * \\
(0.02)\end{array}$ & $\begin{array}{c}0.69 * * * \\
(0.02)\end{array}$ & $\begin{array}{c}0.70^{* * *} \\
(0.02)\end{array}$ & $\begin{array}{c}0.70^{* * *} \\
(0.02)\end{array}$ & $\begin{array}{c}0.70^{* * *} \\
(0.02)\end{array}$ & $\begin{array}{c}0.69^{* * *} \\
(0.03)\end{array}$ & $\begin{array}{c}0.69 * * * \\
(0.02)\end{array}$ & $\begin{array}{c}0.70^{* * *} \\
(0.03)\end{array}$ & $\begin{array}{l}-0.30 \\
(0.30)\end{array}$ \\
\hline Pre-Treatment GPA & & & & & & & & & & $\begin{array}{c}0.16^{* * * *} \\
(0.05)\end{array}$ \\
\hline $\begin{array}{l}\text { Major \& Cohort FEs } \\
\text { Demographic Characte }\end{array}$ & eristics & & Y & $\mathrm{Y}$ & Y & Y & Y & Y & Y & $\mathrm{Y}$ \\
\hline Low Income & & & $\begin{array}{c}0.02 \\
(0.03)\end{array}$ & $\begin{array}{l}-0.04 \\
(0.04)\end{array}$ & $\begin{array}{c}0.02 \\
(0.03)\end{array}$ & $\begin{array}{c}0.02 \\
(0.03)\end{array}$ & $\begin{array}{l}0.02 \\
(0.03)\end{array}$ & $\begin{array}{c}0.02 \\
(0.03)\end{array}$ & $\begin{array}{l}-0.04 \\
(0.04)\end{array}$ & $\begin{array}{l}-0.05 \\
(0.03)\end{array}$ \\
\hline Female & & & $\begin{array}{c}0.06^{* * *} \\
(0.02)\end{array}$ & $\begin{array}{c}0.06^{* * * *} \\
(0.02)\end{array}$ & $\begin{array}{l}0.05^{* *} \\
(0.02)\end{array}$ & $\begin{array}{c}0.06^{* * *} \\
(0.02)\end{array}$ & $\begin{array}{l}0.06 * * * \\
(0.02)\end{array}$ & $\begin{array}{c}0.06^{* * *} \\
(0.02)\end{array}$ & $\begin{array}{l}0.05 * * \\
(0.02)\end{array}$ & $\begin{array}{c}0.05^{* *} \\
(0.02)\end{array}$ \\
\hline Foreign & & & $\begin{array}{c}-0.08^{* *} \\
(0.03)\end{array}$ & $\begin{array}{c}-0.08^{* *} \\
(0.03)\end{array}$ & $\begin{array}{c}-0.08^{* *} \\
(0.03)\end{array}$ & $\begin{array}{l}-0.02 \\
(0.04)\end{array}$ & $\begin{array}{c}-0.09 * * \\
(0.03)\end{array}$ & $\begin{array}{c}-0.08 * * \\
(0.03)\end{array}$ & $\begin{array}{l}-0.03 \\
(0.04)\end{array}$ & $\begin{array}{l}-0.03 \\
(0.04)\end{array}$ \\
\hline In-State Student & & & $\begin{array}{l}-0.00 \\
(0.02)\end{array}$ & $\begin{array}{l}-0.00 \\
(0.02)\end{array}$ & $\begin{array}{l}-0.00 \\
(0.02)\end{array}$ & $\begin{array}{l}-0.00 \\
(0.02)\end{array}$ & $\begin{array}{l}-0.02 \\
(0.02)\end{array}$ & $\begin{array}{l}-0.00 \\
(0.02)\end{array}$ & $\begin{array}{l}-0.01 \\
(0.02)\end{array}$ & $\begin{array}{l}-0.02 \\
(0.02)\end{array}$ \\
\hline Older & & & $\begin{array}{l}-0.02 \\
(0.02)\end{array}$ & $\begin{array}{l}-0.02 \\
(0.02)\end{array}$ & $\begin{array}{l}-0.02 \\
(0.02)\end{array}$ & $\begin{array}{l}-0.02 \\
(0.02)\end{array}$ & $\begin{array}{l}-0.02 \\
(0.02)\end{array}$ & $\begin{array}{l}-0.02 \\
(0.02)\end{array}$ & $\begin{array}{l}-0.02 \\
(0.02)\end{array}$ & $\begin{array}{l}-0.02 \\
(0.02)\end{array}$ \\
\hline Adjusted R-squared & 0.50 & 0.50 & 0.52 & 0.52 & 0.52 & 0.52 & 0.52 & 0.52 & 0.52 & 0.52 \\
\hline
\end{tabular}

Note. ${ }^{* * *} \mathrm{p}<0.01,{ }^{* *} \mathrm{p}<0.05,{ }^{*} \mathrm{p}<0.1$. Robust standard errors in parentheses. Constant terms not reported in those models where they are estimated (i.e., without fixed effects). No. obs $=1,787$ individuals. The table shows that while those receiving early work experience attain slightly lower grades than they would otherwise, the effect is not statistically significant. Low-income, female, and in-state students receiving early work experience attain higher grades. Foreign students (a broad and heterogeneous group) receiving the early treatment attain lower grades, on average, than they would otherwise. 
Table 4 Effect of Incrementally Earlier Professional Labor Market Experience on Graduation Rate

\begin{tabular}{|c|c|c|c|c|c|c|c|c|c|c|}
\hline \multirow{2}{*}{$\begin{array}{r}\text { Dep. Var: } \\
\text { Model: }\end{array}$} & \multicolumn{10}{|c|}{ Graduated } \\
\hline & (1) & (2) & (3) & (4) & (5) & (6) & (7) & (8) & (9) & (10) \\
\hline \multicolumn{11}{|l|}{ Treatment Effects } \\
\hline Early Job Treatment & $\begin{array}{l}-0.02 * \\
(0.01)\end{array}$ & $\begin{array}{c}0.03 \\
(0.13)\end{array}$ & $\begin{array}{l}-0.02 * \\
(0.01)\end{array}$ & $\begin{array}{c}-0.03 * * \\
(0.01)\end{array}$ & $\begin{array}{l}-0.03 * \\
(0.01)\end{array}$ & $\begin{array}{c}-0.03 * * \\
(0.01)\end{array}$ & $\begin{array}{c}-0.04 * * * \\
(0.01)\end{array}$ & $\begin{array}{c}-0.02 \\
(0.01)\end{array}$ & $\begin{array}{c}-0.05 * * * \\
(0.02)\end{array}$ & $\begin{array}{c}0.21 \\
(0.86)\end{array}$ \\
\hline Early Job $\times G P A$ & & $\begin{array}{l}-0.01 \\
(0.04)\end{array}$ & & & & & & & & $\begin{array}{l}-0.16 \\
(0.52)\end{array}$ \\
\hline Early Job $\times G P A^{\wedge} 2$ & & & & & & & & & & $\begin{array}{c}0.02 \\
(0.08)\end{array}$ \\
\hline Early Job $\times$ Low Incom & & & & $\begin{array}{c}0.05 \\
(0.08)\end{array}$ & & & & & $\begin{array}{c}0.06 \\
(0.08)\end{array}$ & $\begin{array}{c}0.06 \\
(0.08)\end{array}$ \\
\hline Early Job $\times$ Female & & & & & $\begin{array}{c}0.01 \\
(0.03)\end{array}$ & & & & $\begin{array}{c}0.01 \\
(0.02)\end{array}$ & $\begin{array}{c}0.01 \\
(0.02)\end{array}$ \\
\hline Early Job $\times$ Foreign & & & & & & $\begin{array}{c}0.09 \\
(0.06)\end{array}$ & & & $\begin{array}{l}0.12^{*} \\
(0.06)\end{array}$ & $\begin{array}{l}0.12^{*} \\
(0.06)\end{array}$ \\
\hline Early Job $\times$ In-State & & & & & & & $\begin{array}{l}0.05^{*} \\
(0.03)\end{array}$ & & $\begin{array}{c}0.06^{* *} \\
(0.03)\end{array}$ & $\begin{array}{l}0.06^{* *} \\
(0.03)\end{array}$ \\
\hline Early Job $\times$ Older & & & & & & & & $\begin{array}{l}-0.02 \\
(0.03)\end{array}$ & $\begin{array}{l}-0.03 \\
(0.03)\end{array}$ & $\begin{array}{l}-0.04 \\
(0.03)\end{array}$ \\
\hline \multicolumn{11}{|c|}{ Academic Characteristics } \\
\hline Pre-Treatment GPA & $\begin{array}{c}0.09 * * * \\
(0.02)\end{array}$ & $\begin{array}{c}0.10^{* * *} \\
(0.03)\end{array}$ & $\begin{array}{c}0.89 * * * \\
(0.26)\end{array}$ & $\begin{array}{c}0.89 * * * \\
(0.26)\end{array}$ & $\begin{array}{c}0.89 * * * \\
(0.26)\end{array}$ & $\begin{array}{c}0.88^{* * *} \\
(0.26)\end{array}$ & $\begin{array}{c}0.89 * * * \\
(0.26)\end{array}$ & $\begin{array}{c}0.89 * * * \\
(0.26)\end{array}$ & $\begin{array}{c}0.87^{* * * *} \\
(0.26)\end{array}$ & $\begin{array}{c}0.95 * * * \\
(0.34)\end{array}$ \\
\hline Pre-Treatment GPA & & & $-0.12 * * *$ & $-0.12 * * *$ & $-0.12 * * *$ & $-0.12 * * *$ & $-0.12 * * *$ & $-0.12 * * *$ & $-0.12^{* * *}$ & $\begin{array}{c}-0.13^{* * * *} \\
(0.05)\end{array}$ \\
\hline Major \& Cohort FEs & & & $\mathrm{Y}$ & $\mathrm{Y}$ & $\mathrm{Y}$ & $\mathrm{Y}$ & Y & $\mathrm{Y}$ & $\mathrm{Y}$ & $\mathrm{Y}$ \\
\hline Demographic Characte & eristics & & & & & & & & & \\
\hline Low Income & & & $\begin{array}{c}0.01 \\
(0.04)\end{array}$ & $\begin{array}{l}-0.03 \\
(0.07)\end{array}$ & $\begin{array}{c}0.01 \\
(0.04)\end{array}$ & $\begin{array}{c}0.01 \\
(0.04)\end{array}$ & $\begin{array}{c}0.01 \\
(0.04)\end{array}$ & $\begin{array}{c}0.01 \\
(0.04)\end{array}$ & $\begin{array}{l}-0.03 \\
(0.06)\end{array}$ & $\begin{array}{l}-0.03 \\
(0.06)\end{array}$ \\
\hline Female & & & $\begin{array}{l}0.03^{*} \\
(0.01)\end{array}$ & $\begin{array}{c}0.03 * * \\
(0.01)\end{array}$ & $\begin{array}{c}0.02 \\
(0.02)\end{array}$ & $\begin{array}{l}0.03^{*} \\
(0.01)\end{array}$ & $\begin{array}{l}0.03^{*} \\
(0.01)\end{array}$ & $\begin{array}{l}0.03 * \\
(0.01)\end{array}$ & $\begin{array}{c}0.02 \\
(0.02)\end{array}$ & $\begin{array}{c}0.02 \\
(0.02)\end{array}$ \\
\hline Foreign & & & $\begin{array}{l}-0.04 \\
(0.03)\end{array}$ & $\begin{array}{l}-0.04 \\
(0.03)\end{array}$ & $\begin{array}{l}-0.04 \\
(0.03)\end{array}$ & $\begin{array}{l}-0.08 \\
(0.05)\end{array}$ & $\begin{array}{l}-0.04 \\
(0.03)\end{array}$ & $\begin{array}{l}-0.04 \\
(0.03)\end{array}$ & $\begin{array}{l}-0.10^{*} \\
(0.05)\end{array}$ & $\begin{array}{c}-0.10^{*} \\
(0.05)\end{array}$ \\
\hline In-State Student & & & $\begin{array}{c}0.01 \\
(0.01)\end{array}$ & $\begin{array}{c}0.00 \\
(0.01)\end{array}$ & $\begin{array}{c}0.01 \\
(0.01)\end{array}$ & $\begin{array}{c}0.01 \\
(0.01)\end{array}$ & $\begin{array}{l}-0.02 \\
(0.02)\end{array}$ & $\begin{array}{c}0.00 \\
(0.01)\end{array}$ & $\begin{array}{l}-0.03 * \\
(0.02)\end{array}$ & $\begin{array}{l}-0.03 * \\
(0.02)\end{array}$ \\
\hline Older & & & $\begin{array}{c}-0.03 * * \\
(0.02)\end{array}$ & $\begin{array}{c}-0.03 * * \\
(0.02)\end{array}$ & $\begin{array}{c}-0.03 * * \\
(0.02)\end{array}$ & $\begin{array}{c}-0.03 * * \\
(0.02)\end{array}$ & $\begin{array}{c}-0.03^{* *} \\
(0.02)\end{array}$ & $\begin{array}{l}-0.02 \\
(0.02)\end{array}$ & $\begin{array}{l}-0.01 \\
(0.02)\end{array}$ & $\begin{array}{l}-0.01 \\
(0.02)\end{array}$ \\
\hline Adjusted R-squared & 0.03 & 0.03 & 0.06 & 0.06 & 0.06 & 0.06 & 0.06 & 0.06 & 0.06 & 0.06 \\
\hline
\end{tabular}

Note. ${ }^{* * *} \mathrm{p}<0.01,{ }^{* *} \mathrm{p}<0.05,{ }^{*} \mathrm{p}<0.1$. Robust standard errors in parentheses. Constant terms not reported in those models where they are estimated (i.e., without fixed effects). No. obs $=1,787$ individuals. The table shows that graduation rates (i.e. graduating within the observation period, not necessarily failing) are lower among those who gain early experience. Those receiving early work experience attain slightly lower grades than they would otherwise, the effect is not statistically significant. This is not true of females and low-income students (who tend to be stronger students, as a group). Foreign and in-state students increase their graduation rate when given the early exposure. 


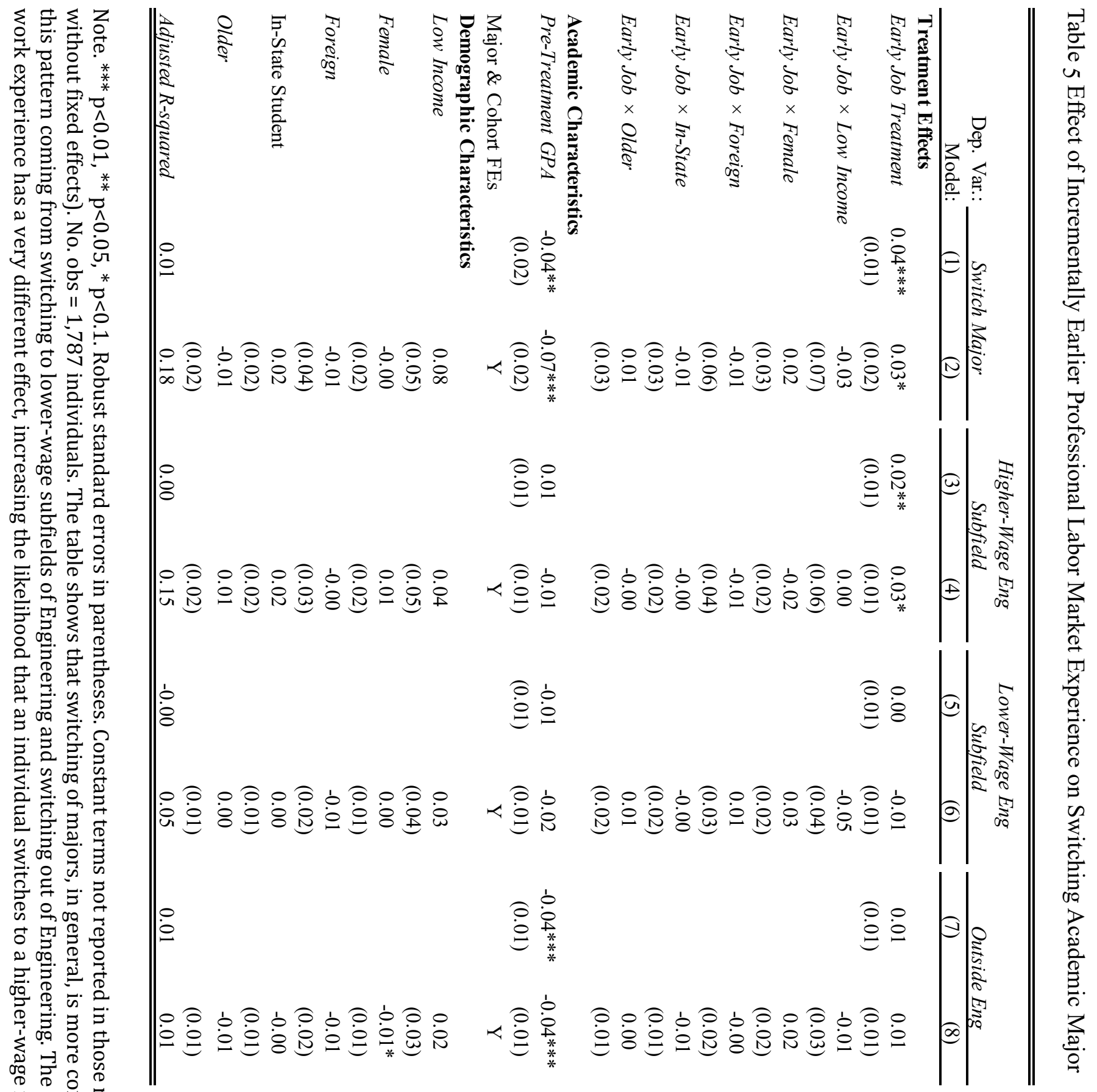


Table 6 Transition Matrix of Pre- and Post- Treatment Academic Majors

\begin{tabular}{rccccccc}
\hline \hline & \multicolumn{7}{c}{ Pre-Treament Major } \\
\cline { 2 - 8 } Pre-Treament Major & Computer & Chemical & Civil & Computer & Electrical & Mechanical & Total: \\
\hline Computer & 163 & 2 & 0 & 40 & 20 & 11 & 236 \\
Chemical & 0 & 303 & 0 & 0 & 0 & 2 & 305 \\
Civil & 0 & 2 & 266 & 0 & 1 & 0 & 269 \\
Electrical-Computer & 10 & 0 & 0 & 61 & 19 & 0 & 90 \\
Electrical & 6 & 3 & 2 & 17 & 134 & 3 & 165 \\
Industrial & 0 & 3 & 2 & 0 & 3 & 6 & 13 \\
Mechanical & 3 & 2 & 6 & 0 & 2 & 662 & 670 \\
Outside Engineering & 3 & 8 & 7 & 3 & 5 & 13 & 39 \\
\hline Total: & 185 & 323 & 283 & 121 & 184 & 691 & 1,796 \\
\hline \hline
\end{tabular}

Note. ${ }^{* *} \mathrm{p}<0.01,{ }^{* *} \mathrm{p}<0.05,{ }^{*} \mathrm{p}<0.1$. Robust standard errors in parentheses. Constant terms not reported in those models where they are estimated (i.e., without fixed effects). No. obs $=1,787$ individuals. The table reports that large blocks of students in Electrical-Computer, Electrical and Mechanical Engineers switch to Computer. Many Electrical-Computer Engineers also switch to Electrical. A small set of students, distributed somewhat evenly across all Engineering majors, leave Engineering. 
Table 7 Effect of Incrementally Earlier Professional Labor Market Experience on Course Choices

\begin{tabular}{|c|c|c|c|c|c|c|c|c|c|c|}
\hline \multirow{2}{*}{$\begin{array}{r}\text { Dep. Var.: } \\
\text { Model: }\end{array}$} & \multicolumn{10}{|c|}{ Post-Treatment Percent Courses in Engineering } \\
\hline & $(1)$ & $(2)$ & (3) & $(4)$ & $(5)$ & $(6)$ & $(7)$ & $(8)$ & $(9)$ & $(10)$ \\
\hline \multicolumn{11}{|l|}{ Treatment Effects } \\
\hline Early Job Treatment & $\begin{array}{c}0.02 * * * \\
(0.01)\end{array}$ & $\begin{array}{l}-0.01 \\
(0.05)\end{array}$ & $\begin{array}{c}0.02 * * * \\
(0.00)\end{array}$ & $\begin{array}{c}0.02 * * * \\
(0.00)\end{array}$ & $\begin{array}{c}0.03 * * * \\
(0.01)\end{array}$ & $\begin{array}{c}0.02 * * * \\
(0.01)\end{array}$ & $\begin{array}{c}0.02 * * * \\
(0.01)\end{array}$ & $\begin{array}{c}0.02 * * * \\
(0.01)\end{array}$ & $\begin{array}{l}0.01 * \\
(0.01)\end{array}$ & $\begin{array}{c}0.28 \\
(0.23)\end{array}$ \\
\hline Early Job $\times G P A$ & & $\begin{array}{c}0.01 \\
(0.01)\end{array}$ & & & & & & & & $\begin{array}{l}-0.19 \\
(0.14)\end{array}$ \\
\hline Early Job $\times G P A^{\wedge} 2$ & & & & & & & & & & $\begin{array}{c}0.03 \\
(0.02)\end{array}$ \\
\hline \multicolumn{2}{|l|}{ Early Job $\times$ Low Income } & & & $\begin{array}{c}0.02 \\
(0.03)\end{array}$ & & & & & $\begin{array}{c}0.02 \\
(0.03)\end{array}$ & $\begin{array}{c}0.02 \\
(0.03)\end{array}$ \\
\hline Early Job $\times$ Female & & & & & $\begin{array}{l}-0.00 \\
(0.01)\end{array}$ & & & & $\begin{array}{l}-0.00 \\
(0.01)\end{array}$ & $\begin{array}{l}-0.01 \\
(0.01)\end{array}$ \\
\hline Early Job $\times$ Foreign & & & & & & $\begin{array}{c}0.03 \\
(0.02)\end{array}$ & & & $\begin{array}{c}0.03 \\
(0.02)\end{array}$ & $\begin{array}{l}0.04^{*} \\
(0.02)\end{array}$ \\
\hline Early Job $\times$ In-State & & & & & & & $\begin{array}{c}0.01 \\
(0.01)\end{array}$ & & $\begin{array}{c}0.01 \\
(0.01)\end{array}$ & $\begin{array}{c}0.01 \\
(0.01)\end{array}$ \\
\hline Early Job $\times$ Older & & & & & & & & $\begin{array}{c}0.02 \\
(0.01)\end{array}$ & $\begin{array}{c}0.01 \\
(0.01)\end{array}$ & $\begin{array}{c}0.01 \\
(0.01)\end{array}$ \\
\hline \multicolumn{11}{|c|}{ Academic Characteristics } \\
\hline Pre-Treatment GPA & $\begin{array}{c}0.00 \\
(0.01)\end{array}$ & $\begin{array}{l}-0.00 \\
(0.01)\end{array}$ & $\begin{array}{c}0.02 * * * \\
(0.01)\end{array}$ & $\begin{array}{c}0.02 * * * \\
(0.01)\end{array}$ & $\begin{array}{c}0.02 * * * \\
(0.01)\end{array}$ & $\begin{array}{c}0.02 * * * \\
(0.01)\end{array}$ & $\begin{array}{c}0.02 * * * \\
(0.01)\end{array}$ & $\begin{array}{c}0.02 * * * \\
(0.01)\end{array}$ & $\begin{array}{c}0.02 * * * \\
(0.01)\end{array}$ & $\begin{array}{c}0.14 \\
(0.09)\end{array}$ \\
\hline Pre-Treatment GPA & & & & & & & & & & $\begin{array}{l}-0.02 \\
(0.01)\end{array}$ \\
\hline Major \& Cohort FEs & & & Y & Y & Y & Y & $\mathrm{Y}$ & $\mathrm{Y}$ & $\mathrm{Y}$ & $\mathrm{Y}$ \\
\hline \multicolumn{11}{|c|}{ Demographic Characteristics } \\
\hline Low Income & & & $\begin{array}{c}-0.02 \\
(0.01)\end{array}$ & $\begin{array}{l}-0.03 \\
(0.02)\end{array}$ & $\begin{array}{l}-0.02 \\
(0.01)\end{array}$ & $\begin{array}{l}-0.02 \\
(0.01)\end{array}$ & $\begin{array}{l}-0.02 \\
(0.01)\end{array}$ & $\begin{array}{l}-0.02 \\
(0.01)\end{array}$ & $\begin{array}{l}-0.03 \\
(0.02)\end{array}$ & $\begin{array}{l}-0.03 \\
(0.02)\end{array}$ \\
\hline Female & & & $\begin{array}{l}-0.00 \\
(0.01)\end{array}$ & $\begin{array}{c}-0.00 \\
(0.01)\end{array}$ & $\begin{array}{c}0.00 \\
(0.01)\end{array}$ & $\begin{array}{l}-0.00 \\
(0.01)\end{array}$ & $\begin{array}{l}-0.00 \\
(0.01)\end{array}$ & $\begin{array}{c}-0.00 \\
(0.01)\end{array}$ & $\begin{array}{c}0.00 \\
(0.01)\end{array}$ & $\begin{array}{c}0.00 \\
(0.01)\end{array}$ \\
\hline Foreign & & & $\begin{array}{c}0.02 * * \\
(0.01)\end{array}$ & $\begin{array}{c}0.02 * * \\
(0.01)\end{array}$ & $\begin{array}{c}0.02 * * \\
(0.01)\end{array}$ & $\begin{array}{c}0.01 \\
(0.02)\end{array}$ & $\begin{array}{c}0.02 * * \\
(0.01)\end{array}$ & $\begin{array}{c}0.02 * * \\
(0.01)\end{array}$ & $\begin{array}{c}0.01 \\
(0.02)\end{array}$ & $\begin{array}{c}0.01 \\
(0.02)\end{array}$ \\
\hline In-State Student & & & $\begin{array}{c}-0.00 \\
(0.01)\end{array}$ & $\begin{array}{c}-0.00 \\
(0.01)\end{array}$ & $\begin{array}{c}-0.00 \\
(0.01)\end{array}$ & $\begin{array}{r}-0.00 \\
(0.01)\end{array}$ & $\begin{array}{c}-0.00 \\
(0.01)\end{array}$ & $\begin{array}{c}0.00 \\
(0.01)\end{array}$ & $\begin{array}{l}-0.01 \\
(0.01)\end{array}$ & $\begin{array}{l}-0.01 \\
(0.01)\end{array}$ \\
\hline Older & & & $\begin{array}{c}0.02 * * * \\
(0.01)\end{array}$ & $\begin{array}{c}0.02 * * * \\
(0.01)\end{array}$ & $\begin{array}{c}0.02 * * * \\
(0.01)\end{array}$ & $\begin{array}{c}0.02 * * * \\
(0.01)\end{array}$ & $\begin{array}{c}0.02 * * * \\
(0.01)\end{array}$ & $\begin{array}{c}0.01 \\
(0.01)\end{array}$ & $\begin{array}{c}0.01 \\
(0.01)\end{array}$ & $\begin{array}{c}0.01 \\
(0.01)\end{array}$ \\
\hline Adjusted R-squared & 0.00 & 0.00 & 0.43 & 0.43 & 0.43 & 0.43 & 0.43 & 0.43 & 0.43 & 0.43 \\
\hline
\end{tabular}

Note. ${ }^{* * *} \mathrm{p}<0.01,{ }^{* *} \mathrm{p}<0.05,{ }^{*} \mathrm{p}<0.1$. Robust standard errors in parentheses. Constant terms not reported in those models where they are estimated (i.e., without fixed effects). No. obs $=1,787$ individuals. The table reports a general tendency for students with higher-GPAs to take more Engineering courses, and a general tendency for foregin and older students to take Engineering a greater number of Engineering courses. Students who receive early exposure to work experience generally tend to later choose to take a greater number of courses in Engineering. This is especially so, on average, among foreign students. 


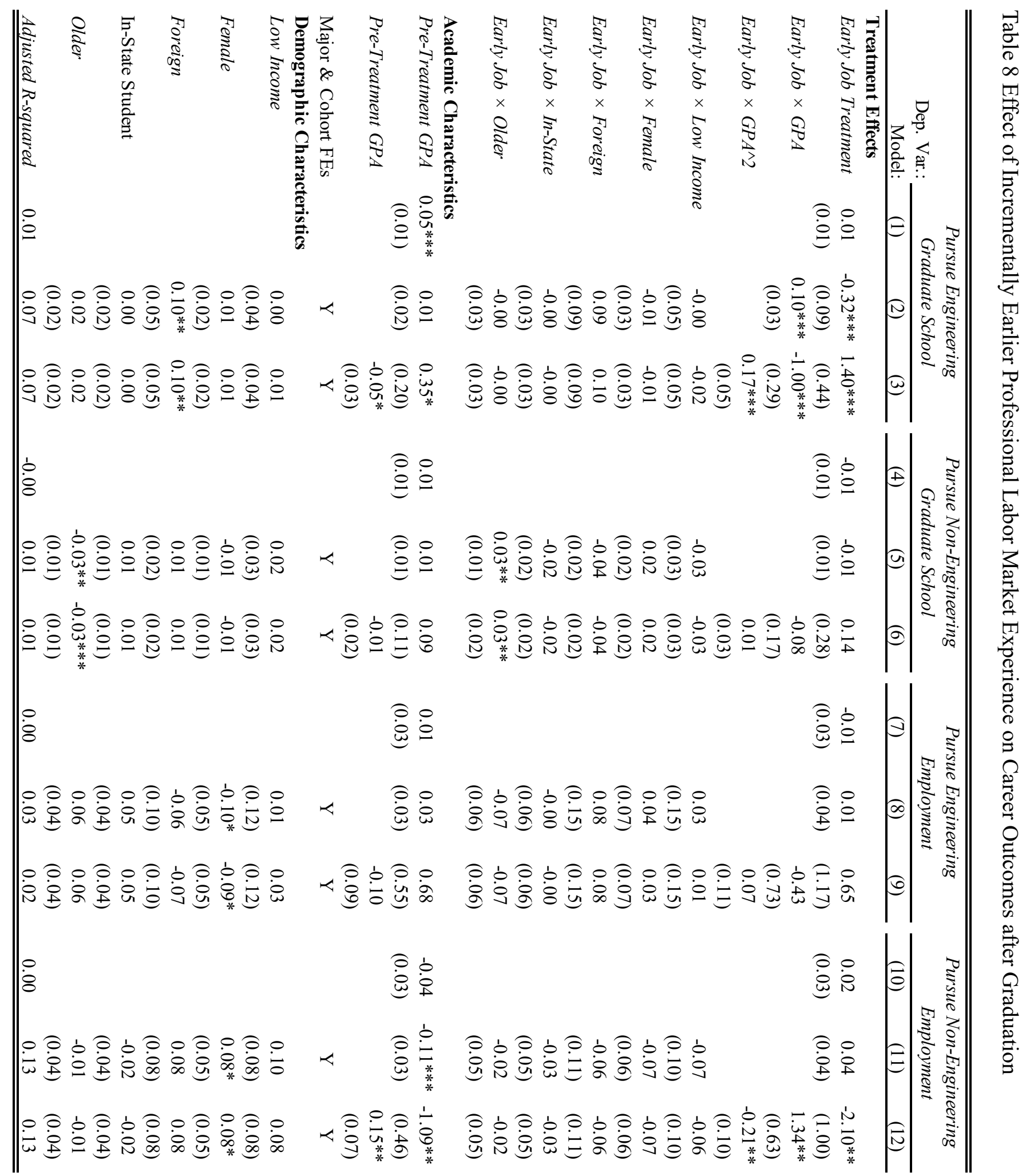




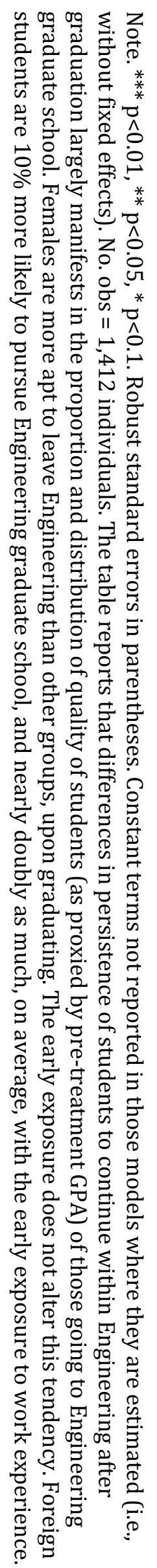


Table 9 Effect of Incrementally Earlier Professional Labor Market Experience on Employment Outcomes

\begin{tabular}{|c|c|c|c|c|c|c|c|c|c|c|}
\hline \multirow{2}{*}{$\begin{array}{r}\text { Dep. Var:: } \\
\text { Model: }\end{array}$} & \multicolumn{8}{|c|}{ Wage } & \multicolumn{2}{|c|}{ Employer Size } \\
\hline & (1) & (2) & (3) & (4) & $(5)$ & (6) & (7) & $(8)$ & $(9)$ & $(10)$ \\
\hline \multicolumn{11}{|l|}{ Treatment Effects } \\
\hline Early Job Treatment & $\begin{array}{c}0.20 \\
(0.21)\end{array}$ & $\begin{array}{c}0.01 \\
(0.20)\end{array}$ & $\begin{array}{c}0.14 \\
(0.22)\end{array}$ & $\begin{array}{c}0.07 \\
(0.20)\end{array}$ & $\begin{array}{c}0.22 \\
(0.23)\end{array}$ & $\begin{array}{c}0.23 \\
(0.23)\end{array}$ & $\begin{array}{c}0.26 \\
(0.31)\end{array}$ & $\begin{array}{l}-6.98 \\
(8.68)\end{array}$ & $\begin{array}{l}-0.09 \\
(0.67)\end{array}$ & $\begin{array}{c}12.77 \\
(18.92)\end{array}$ \\
\hline Early Job $\times G P A$ & & & & & & & & $\begin{array}{c}4.92 \\
(5.47)\end{array}$ & & $\begin{array}{c}-8.40 \\
(11.90)\end{array}$ \\
\hline Early Job $\times G P A^{\wedge} 2$ & & & & & & & & $\begin{array}{c}-0.81 \\
(0.85)\end{array}$ & & $\begin{array}{c}1.34 \\
(1.85)\end{array}$ \\
\hline \multicolumn{2}{|l|}{ Early Job $\times$ Low Income } & $\begin{array}{c}1.81 * * \\
(0.80)\end{array}$ & & & & & $\begin{array}{c}1.81 * * \\
(0.80)\end{array}$ & $\begin{array}{c}1.92 * * \\
(0.80)\end{array}$ & $\begin{array}{l}4.24 * \\
(2.28)\end{array}$ & $\begin{array}{l}4.13^{*} \\
(2.30)\end{array}$ \\
\hline Early Job $\times$ Female & & & $\begin{array}{l}-0.19 \\
(0.45)\end{array}$ & & & & $\begin{array}{l}-0.37 \\
(0.47)\end{array}$ & $\begin{array}{l}-0.32 \\
(0.48)\end{array}$ & $\begin{array}{c}0.12 \\
(1.09)\end{array}$ & $\begin{array}{c}0.10 \\
(1.09)\end{array}$ \\
\hline Early Job $\times$ Foreign & & & & $\begin{array}{c}0.39 \\
(0.94)\end{array}$ & & & $\begin{array}{c}0.44 \\
(0.97)\end{array}$ & $\begin{array}{c}0.41 \\
(0.98)\end{array}$ & $\begin{array}{l}-1.51 \\
(2.39)\end{array}$ & $\begin{array}{l}-1.47 \\
(2.40)\end{array}$ \\
\hline Early Job $\times$ In-State & & & & & $\begin{array}{l}-0.38 \\
(0.41)\end{array}$ & & $\begin{array}{l}-0.24 \\
(0.42)\end{array}$ & $\begin{array}{l}-0.23 \\
(0.42)\end{array}$ & $\begin{array}{c}0.95 \\
(0.95)\end{array}$ & $\begin{array}{c}0.95 \\
(0.95)\end{array}$ \\
\hline Early Job $\times$ Older & & & & & & $\begin{array}{l}-0.46 \\
(0.42)\end{array}$ & $\begin{array}{l}-0.44 \\
(0.44)\end{array}$ & $\begin{array}{l}-0.44 \\
(0.44)\end{array}$ & $\begin{array}{l}-0.64 \\
(1.00)\end{array}$ & $\begin{array}{l}-0.68 \\
(1.00)\end{array}$ \\
\hline \multicolumn{11}{|c|}{ Academic Characteristics } \\
\hline Pre-Treatment GPA & $\begin{array}{c}2.31 * * * \\
(0.25)\end{array}$ & $\begin{array}{c}1.92 * * * \\
(0.24)\end{array}$ & $\begin{array}{c}1.91 * * * \\
(0.23)\end{array}$ & $\begin{array}{c}1.91 * * * \\
(0.23)\end{array}$ & $\begin{array}{c}1.91 * * * \\
(0.23)\end{array}$ & $\begin{array}{c}1.91 * * * \\
(0.23)\end{array}$ & $\begin{array}{c}1.92 * * * \\
(0.23)\end{array}$ & $\begin{array}{l}-2.63 \\
(3.82)\end{array}$ & $\begin{array}{l}-0.24 \\
(0.51)\end{array}$ & $\begin{array}{l}-0.57 \\
(9.03)\end{array}$ \\
\hline Pre-Treatment GPA & & & & & & & & $\begin{array}{c}0.73 \\
(0.60)\end{array}$ & & $\begin{array}{c}0.04 \\
(1.40)\end{array}$ \\
\hline Major \& Cohort FEs & & $\mathrm{Y}$ & $\mathrm{Y}$ & $\mathrm{Y}$ & $\mathrm{Y}$ & $\mathrm{Y}$ & Y & $\mathrm{Y}$ & $\mathrm{Y}$ & $\mathrm{Y}$ \\
\hline \multicolumn{11}{|c|}{ Demographic Characteristics } \\
\hline Low Income & & $\begin{array}{c}-0.98 * \\
(0.51)\end{array}$ & $\begin{array}{c}0.15 \\
(0.46)\end{array}$ & $\begin{array}{c}0.16 \\
(0.46)\end{array}$ & $\begin{array}{c}0.16 \\
(0.46)\end{array}$ & $\begin{array}{c}0.16 \\
(0.46)\end{array}$ & $\begin{array}{l}-0.97 * \\
(0.51)\end{array}$ & $\begin{array}{c}-1.06 * * \\
(0.51)\end{array}$ & $\begin{array}{l}-2.34 \\
(1.61)\end{array}$ & $\begin{array}{l}-2.31 \\
(1.64)\end{array}$ \\
\hline Female & & $\begin{array}{c}0.02 \\
(0.24)\end{array}$ & $\begin{array}{c}0.11 \\
(0.36)\end{array}$ & $\begin{array}{c}-0.00 \\
(0.24)\end{array}$ & $\begin{array}{c}-0.00 \\
(0.25)\end{array}$ & $\begin{array}{c}-0.01 \\
(0.24)\end{array}$ & $\begin{array}{c}0.22 \\
(0.37)\end{array}$ & $\begin{array}{c}0.19 \\
(0.37)\end{array}$ & $\begin{array}{l}-0.66 \\
(0.83)\end{array}$ & $\begin{array}{l}-0.66 \\
(0.83)\end{array}$ \\
\hline Foreign & & $\begin{array}{c}-2.64 * * * \\
(0.50)\end{array}$ & $\begin{array}{c}-2.64 * * * \\
(0.50)\end{array}$ & $\begin{array}{c}-2.83 * * * \\
(0.67)\end{array}$ & $\begin{array}{c}-2.63 * * * \\
(0.50)\end{array}$ & $\begin{array}{c}-2.65 * * * \\
(0.50)\end{array}$ & $\begin{array}{c}-2.84 * * * \\
(0.69)\end{array}$ & $\begin{array}{c}-2.81 * * * \\
(0.69)\end{array}$ & $\begin{array}{c}1.21 \\
(1.65)\end{array}$ & $\begin{array}{c}1.20 \\
(1.66)\end{array}$ \\
\hline In-State & & $\begin{array}{l}-0.18 \\
(0.21)\end{array}$ & $\begin{array}{c}-0.17 \\
(0.21)\end{array}$ & $\begin{array}{c}-0.17 \\
(0.21)\end{array}$ & $\begin{array}{c}0.04 \\
(0.32)\end{array}$ & $\begin{array}{c}-0.18 \\
(0.21)\end{array}$ & $\begin{array}{c}-0.06 \\
(0.32)\end{array}$ & $\begin{array}{c}-0.07 \\
(0.32)\end{array}$ & $\begin{array}{l}-0.54 \\
(0.71)\end{array}$ & $\begin{array}{l}-0.54 \\
(0.71)\end{array}$ \\
\hline Older & & $\begin{array}{l}-0.10 \\
(0.22)\end{array}$ & $\begin{array}{l}-0.09 \\
(0.22)\end{array}$ & $\begin{array}{l}-0.09 \\
(0.22)\end{array}$ & $\begin{array}{l}-0.10 \\
(0.22)\end{array}$ & $\begin{array}{c}0.16 \\
(0.33)\end{array}$ & $\begin{array}{c}0.12 \\
(0.34)\end{array}$ & $\begin{array}{c}0.13 \\
(0.34)\end{array}$ & $\begin{array}{c}0.44 \\
(0.74)\end{array}$ & $\begin{array}{c}0.44 \\
(0.74)\end{array}$ \\
\hline Adjusted R-squared & 0.05 & 0.21 & 0.21 & 0.21 & 0.21 & 0.21 & 0.21 & 0.21 & 0 & 0.01 \\
\hline
\end{tabular}

Note. $* * * \mathrm{p}<0.01, * * \mathrm{p}<0.05, * \mathrm{p}<0$. I. Robust standard errors in parentheses. Constant terms not reported in those models where they are estimated (i.e., without fixed effects). No. obs $=$ I, 787 individuals. The table reports that while it appears that, as a baseline, low-income students earn lower wages and join smaller firms, earlier exposure to work experience more than makes up for this difference. Foreign students, on average, earn lower wages (and join larger companies). 
Table Io Effect of Quality of First Job Labor Market Experience on Employment Outcomes

\begin{tabular}{|c|c|c|c|c|c|c|}
\hline \multirow{3}{*}{$\begin{array}{r}\text { Dep. Var:: } \\
\text { Specification: } \\
\text { Model: }\end{array}$} & \multirow{2}{*}{\multicolumn{2}{|c|}{$\frac{\text { Wage in First Exposure }}{\text { First-Stage OLS }}$}} & \multicolumn{2}{|c|}{ Post-Treatment GPA } & \multicolumn{2}{|c|}{ Graduated } \\
\hline & & & \multirow{2}{*}{$\frac{O L S}{(3)}$} & \multirow{2}{*}{$\frac{I V}{(4)}$} & \multirow{2}{*}{$\begin{array}{c}O L S \\
(5) \\
\end{array}$} & \multirow{2}{*}{$\begin{array}{l}I V \\
(6) \\
\end{array}$} \\
\hline & $(1)$ & $(2)$ & & & & \\
\hline Wage in First Exposure & & & $\begin{array}{l}0.009 * * * \\
(0.002)\end{array}$ & $\begin{array}{c}0.005 \\
(0.005)\end{array}$ & $\begin{array}{l}0.004 * * * \\
(0.001)\end{array}$ & $\begin{array}{l}0.009 * \\
(0.005)\end{array}$ \\
\hline Advisor Dummies & & $\mathrm{Y}$ & & & & \\
\hline Major \& Cohort FEs & Y & $\mathrm{Y}$ & $\mathrm{Y}$ & $\mathrm{Y}$ & $\mathrm{Y}$ & $\mathrm{Y}$ \\
\hline \multicolumn{7}{|c|}{ Demographic Characteristics } \\
\hline Adjusted R-squared & 0.08 & 0.17 & 0.02 & 0.02 & 0.01 & 0.02 \\
\hline
\end{tabular}

Note. ${ }^{* * *} \mathrm{p}<0.01, * * \mathrm{p}<0.05, * \mathrm{p}<0.1$. Robust standard errors in parentheses. No. obs $=1,787$ individuals. Random assignment to advisors explains a (very) large fraction of variation in wages. Exploiting variation in wages projected onto random advisor assignment leads to a positive but small estimate of the causal effect of the wage in first work term on GPA; the estimated effect of variation in wage on graduation rate is significant and positive. 